\title{
JURISDICTION AND APPLICABLE LAW TO CONTRACTS FOR \\ THE SALE OF GOODS AND THE PROVISION OF SERVICES INCLUDING THE CARRIAGE OF GOODS BY SEA AND OTHER MEANS OF TRANSPORT IN THE EUROPEAN UNION
}

\author{
JURISDICCIÓN Y DERECHO APLICABLE A LOS CONTRATOS \\ DE COMPRAVENTA DE MERCADERÍAS Y DE PRESTACIÓN \\ DE SERVICIOS INCLUYENDO EL TRANSPORTE \\ DE MERCANCÍAS POR VÍA MARÍTIMA Y OTROS MEDIOS \\ DE TRANSPORTE EN LA UNIÓN EUROPEA
}

\author{
JonATAN ECHEBARRÍa FERNÁNDEZ* \\ Ph.D. in Law \\ Copenhagen Business School
}

Recibido: 17.05.2019 / Aceptado: 05.06.2019

DOI: https://doi.org/10.20318/cdt.2019.4950

\begin{abstract}
The article analyses the jurisdiction and applicable law to contracts for the sale of goods and the provision of services in the European Union. It particularly focuses on contracts that subsume different categories of contracts, such as the carriage of goods by sea, in a contract for the sale of goods and the provision of services. The European Union law and the interpretation provided by the Court of Justice of the European Union shed light into the place of performance of the contract in order to set jurisdiction for national courts. This is explained through the current legal framework and the case law in order to ascertain where and under what legal regime the claimant may start proceedings for the breach of a contractual obligation or in case of a non-contractual claim.

Keywords: provision of services, sale of goods, carriage of goods by sea and other means of transport, Court of Justice of the European Union, contractual actions, place of performance of the contractual obligation, non-contractual actions, applicable law, game theory, contractual efficiency.

Resumen: El artículo analiza la jurisdicción y la ley aplicable a los contratos para la venta de bienes y la prestación de servicios en la Unión Europea. En particular, se centra en los contratos que subsumen diferentes categorías de contratos, tales como el transporte de mercancías por mar, en un contrato de venta de mercaderías o de prestación de servicios. El Derecho de la Unión Europea y la interpretación dada por el Tribunal de Justicia de la Unión Europea arrojan luz sobre el lugar de cumplimiento del contrato con el fin de establecer el tribunal nacional competente. Esto se explica a través del marco legal actual y casos para determinar dónde y bajo qué régimen legal el demandante puede
\end{abstract}

"I would like to thank Professor J. CARRASCOSA GONZÁLEZ (Chair Professor of Private International Law at the University of Murcia), Professor E. RØSÆG (member of PluriCourts - Centre for the Study of the Legitimate Roles of the Judiciary in the Global Order, University of Oslo) and Professor J. J. ÁLVAREZ RUBIO (Chair of Private International Law at the University of the Basque Country) for their advice during the preparation of this article. 
interponer una demanda por incumplimiento de una obligación contractual o en caso de una reclamación extracontractual.

Palabras clave: prestación de servicios, compraventa de mercaderías, transporte de mercancías por vía marítima y otros medios de transporte, Tribunal de Justicia de la Unión Europea, acciones contractuales, lugar de ejecución de la obligación contractual, acciones extracontractuales, derecho aplicable, teoría de juegos, eficiencia contractual.

Summary: I. Introduction. II. Jurisdiction, place of performance and contract for the carriage of goods by sea including multimodal transport. 1. Contracts for the sale of goods and the provision of services including the carriage of goods by sea: A battle of concepts. 2. Distinction between contracts for the sale of goods and contracts for the provision of services including the carriage of goods by sea: The battle goes on. 3. Place of performance as a ground of jurisdiction in contracts for the sale of goods and the provision of services. 4. A particular case: multiple places of performance with special regard to multimodal transport. 5. Place of performance, INCOTERMS and contracts for the sale of goods. III. Non-contractual actions under Article 7(2) of the Brussels I Recast Regulation. IV. The applicable law to contracts for the provision of services, the sale of goods and complex contracts under European Union Law. 1. The applicable law to contractual claims. 2. The applicable law to non-contractual claims. 3. Cheapest cost avoider, efficiency in the conflict of laws and game theory. V. Final remarks.

\section{Introduction}

1. Goods are sold and services are provided in the modern interconnected world. The article presents an overview of the jurisdiction and applicable law to contracts for the sale of goods and the provision of services. The contract for the sale of goods or the provision of services may include the carriage of goods by different means of transport. The parties can agree to submit their disputes regarding their contract to a concrete European Union (EU) Member State court according to Articles 25 (exclusive jurisdiction agreement) ${ }^{1}$ and 26 (tacit jurisdiction agreement $)^{2}$ of the Brussels I Recast Regulation. ${ }^{3}$

2. In the absence of that choice, the claimant can opt between the "general" forum ${ }^{4}$ of Article 4 of the Brussels I Recast Regulation that coexists, in an alternative jurisdictional relationship, with

${ }^{1}$ The first paragraph of Article 25 state the following: "If the parties, regardless of their domicile, have agreed that a court or the courts of a Member State are to have jurisdiction to settle any disputes which have arisen or which may arise in connection with a particular legal relationship, that court or those courts shall have jurisdiction, unless the agreement is null and void as to its substantive validity under the law of that Member State. Such jurisdiction shall be exclusive unless the parties have agreed otherwise. The agreement conferring jurisdiction shall be either: (a) in writing or evidenced in writing; (b) in a form which accords with practices which the parties have established between themselves; or (c) in international trade or commerce, in a form which accords with a usage of which the parties are or ought to have been aware and which in such trade or commerce is widely known to, and regularly observed by, parties to contracts of the type involved in the particular trade or commerce concerned." Article 25(2) further clarifies that "Any communication by electronic means which provides a durable record of the agreement shall be equivalent to "writing"".

${ }^{2}$ Article 26(1) prescribes that "[...] a court of a Member State before which a defendant enters an appearance shall have jurisdiction. This rule shall not apply where appearance was entered to contest the jurisdiction, or where another court has exclusive jurisdiction by virtue of Article 24."

${ }^{3}$ Regulation (EU) No 1215/2012 of the European Parliament and of the Council of 12 December 2012 on jurisdiction and the recognition and enforcement of judgments in civil and commercial matters [2012] OJ L351/1. Also, its predecessors should be introduced: Council Regulation (EC) 44/2001 of 22 December 2000 on jurisdiction and the recognition and enforcement of judgments in civil and commercial matters, and the Brussels Convention of 27 September 1968 on jurisdiction and the enforcement of judgments in civil and commercial matters, consolidated text of 26 January 1998, OJ 1998 C 27/1.

${ }^{4}$ The "general" forum of the domicile of the defendant in an EU Member State can be defined as a "residual" forum contained in Article 4 of the Brussels I Recast Regulation. The claimant is obliged to start proceedings against the defendant, regardless of its domicile, when a court has exclusive jurisdiction over the dispute contained in Article 24 of the Brussels I Recast Regulation; Vid. J. Carrascosa GonzÁlez, "The defendant's domicile in the Brussels 'The Regulation 1215/2012'. A critical approach of the actor sequitur forum rei rule", CDT, vol. 11, No. 1, pp. 112-138, at pp. 129-130. 
the special jurisdiction in matters related to a contract of Article 7(1) or to non-contractual obligations of Article 7(2) of the Brussels I Recast Regulation. ${ }^{5}$ Although an EU Member State court with special jurisdiction under these Articles "may not be bound to apply the Rome I Regulation ${ }^{6}$ which corresponds to the special jurisdiction, connection between special jurisdiction and applicable law will certainly be much tighter than it used to be". 7 The parties may also agree on the globally recognised international commercial arbitration under the 1958 New York Convention. ${ }^{8}$

3. The article analyses first when the Court of Justice of the European Union (CJEU) interprets the contracts for the sale of goods and the provision of services including the carriage of goods by sea and other means of transport in a contractual scenario. It includes an assessment of where the claimant may start proceedings. The autonomous interpretation of the place of performance including the carriage of goods by sea and multimodal transport follows the analysis considering the role of the INCOTERMS. The determination of the court having jurisdiction in case of non-contractual claims follows the analysis. The freedom of the parties to choose the applicable law to their contract in case of contractual and noncontractual actions is enshrined in Articles 3 of the Rome I Regulation and Article 14(1) of the Rome II Regulation, ${ }^{9}$ respectively. A brief introduction to the applicable legal framework in the absence of a choice of law in both contractual and non-contractual actions is provided leading to an analysis of the efficiency of the cost of conflict from a legal and economic perspective considering game theory and law and economics. The final remarks sum up the findings of the previous section that academics and practitioners may take into consideration.

\section{Jurisdiction, place of performance and contract for the carriage of goods by sea including mul- timodal transport}

\section{Contracts for the sale of goods and the provision of services including the carriage of goods by sea: A battle of concepts}

4. The place of performance for the 'sale of goods' and the 'provision of services' is found in Article 7(1)(b) of the Brussels I Recast Regulation. Guidance is provided in Recital 7 of the preamble to the Rome I Regulation, ${ }^{10}$ where it is stated that provisions of Rome I Regulation should be consistent with the Brussels I Recast Regulation. ${ }^{11}$ The Rome I Regulation adds to Article 4(1)(b) in Recital 17 that "the concept of 'provision of services' and 'sale of goods' should be interpreted in the same way as when applying" Article 7(1) of the Brussels I Recast Regulation ${ }^{12}$ that sets out the following:

${ }^{5}$ J. CARRASCOSA GonzÁLEZ confirms that the case-law of the CJEU confirms the criteria in paragraph 36 of the judgment of 4 October 2018, Feniks Sp. z o.o. v Azteca Products \& Services SL, C-337/17, EU:C:2018:805 where a claim against a fraudulent debtor in the context of an actio pauliana concerning a concession contract for the sale and after-sale of Dutch vehicles; Ibid., at p. 130.

${ }^{6}$ Regulation (EC) No 593/2008 of the European Parliament and of the Council of 17 June 2008 on the law applicable to contractual obligations, OJ 2008 L 177/6, OJ 2009 L 309/87.

7 A. Briggs, Civil jurisdiction and judgments, Informa law from Routledge, 2015 at [2.163].

${ }^{8}$ Convention on the Recognition and Enforcement of Foreign Arbitral Awards (1958 New York Convention), adopted 10 June 1958, entered into force 7 June 1959, 330 UNTS 38. The Convention is in force in 177 Contracting States. The requirements for the validity of the agreement are contained in Article II ("an agreement in writing under which the parties undertake to submit to arbitration all or any differences which have arisen or which may arise between them in respect of a defined legal relationship, whether contractual or not, concerning a subject matter capable of settlement by arbitration"). The substantial requirements under the national law of the Contracting State are found in Article V of the Convention.

${ }^{9}$ Regulation (EC) No 864/2007 of the European Parliament and of the Council of 11 July 2007 on the law applicable to non-contractual obligations, OJ 2007 L 199/40.

${ }^{10}$ The Rome I Regulation (EU Regulation 593/2008) came into force on 17 December 2009, and is applicable to all EU Member States except Denmark.

${ }^{11}$ See e.g. the judgment of 15 March 2011, Koelzschv Grand Duchy of Luxembourg, C-29/10, EU:C:2011:151.

12 N. Enonchong, "The Law Applicable to Demand Guarantees and Counter-Guarantees", Lloyd's Maritime \& Commercial Law Quarterly, 2015, no. 2, pp. 194-215. 
"A person domiciled in a Member State may be sued in another Member State:

(a) in matters relating to a contract, in the courts for the place of performance of the obligation in question;

(b) for the purpose of this provision and unless otherwise agreed, the place of performance of the obligation in question shall be:

- in the case of the sale of goods, the place in a Member State where, under the contract, the goods were delivered or should have been delivered,

- in the case of the provision of services, the place in a Member State where, under the contract, the services were provided or should have been provided;

(c) if point (b) does not apply then point (a) applies";

5. On one hand, contracts for the provision of services that include the carriage of goods are not characterised as international contracts for the sale of goods within the meaning of the first indent of Article 7(1)(b) since their main economic purpose is the provision of services. ${ }^{13}$ On the other hand, the second indent of Article 7(1)(b) provides for jurisdiction in favour of the courts where, under the contract, the services were provided or should have been provided.

6. The CJEU has clarified the criteria followed in order to classify the contracts for the sale of goods and the provision of services. The CJEU held in the Falco case ${ }^{14}$ that "the concept of service implies, at the least, that the party, who provides the service, carries out a particular activity in return for remuneration". ${ }^{15}$ The judge correctly pointed out that services within the meaning of the second indent of Article 7(1)(b) of the Brussels I Recast Regulation have been defined, inter alia, as "employment contracts, contracts for the transport of goods, agency contracts to conclude transactions, health services contracts, consultancy contracts, training contacts and the like". ${ }^{16}$ The court followed the doctrine set out by the Falco judgment in the Krejci case ${ }^{17}$ where the storage of goods was also held to be a service.

7. Well-established companies incorporate other elements to the contracts for the provision of services such as the carriage of goods. In these cases, the national judge will rank the hierarchy of functions within the contract. For instance, the contract may be classified as one for the provision of services and the sale and distribution of goods may be ranked in a secondary place. Moreover, the carriage of goods including the carriage of goods by sea could be listed in fourth or fifth place compared to other contractual obligations that the parties shall perform.

8. These contracts for the provision of services including the carriage of goods constitute an expression of an increased accumulation of legal services and management where the contract does not only provide for legal advice. It supersedes the overarching structure of the contract for the carriage

${ }^{13}$ S. Altmeyer, "Car Trim si sta facendo strada: "contratto di vendita" vs. "contratto di prestazione di servizi" ai fini del foro contrattuale di cui all'art. 5, n. 1, lett. b) Reg. (CE) n. 44/2001", Giur. It., 2014, pp. 1125-1128; A. Di BlaSE, "La giurisdizione competente in materia di compravendita e di prestazione di servizi nel regolamento Bruxelles I", Europa e diritto privato, 2011, pp. 459-480; S. ARNOLD, "Kollisionsrechtliche und international-verfahrensrechtliche Aspekte bei Schadensersatzansprüchen privater Auslandsfonds-Anleger (BGH, S. 563)", IPRax, 2013, no. 6, pp. 525-530; in I. LoreNTE MARTíneZ, Competencia judicial internacional y compraventa internacional de mercaderías. Un estudio de metajurisprudencia analítica (Ph.D. thesis), University of Murcia, 2016, p. 298.

${ }_{14}^{14}$ Judgment of 23 April 2009, Falco Privatstiftung v.Weller-Lindhorst, C-533/07, EU:C:2009:257.

${ }^{15}$ Ibid,paragraph 29; judgment of 19December 2013, Corman-Collins SA vLaMaisondu Whisky SA, C-9/12, EU:C:2013:860, paragraph 37; judgment of 10 September 2015, Holterman Ferho Exploitatie and Others, C47/14, EU:C:2015:574, paragraph 57; judgment of 15 June 2017, Saale Kareda v Stefan Benkö, C-249/16, EU:C:2017:472, paragraph 35; judgment of 8 March 2018, Saey Home \& Garden, C64/17, EU:C:2018:173, paragraph 38; and judgment of 8 May 2019, Brian Andrew Kerr v Pavlo Postnov and Natalia Postnova, C-25/18, EU:C:2019:376, paragraph 39. A license agreement for the concession of intellectual property rights "is not a contract for the provision of services within the meaning" of the second indent of Article 7(1)(b) according to the Opinion of the Advocate General TrstenJaK delivered on 27 January 2009, Falco Privatstiftung and Thomas Rabitsch v Gisela Weller-Lindhorst, C-533/07, EU:C:2009:34, paragraph 75.

${ }_{16}$ Ibid., paragraph 74.

17 Order of 14 November 2013, Krejci Lager \& Umschlagbetriebs GmbH v Olbrich Transport und Logistik GmbH, C-469/12, EU:C:2013:788. 
of goods by sea. ${ }^{18}$ The EU Member State court having jurisdiction to hear the case will apply the EU, international and national rules in force, e.g. general contract law, service provision rules, etc. This affirmation may, however, pose a limitation on party autonomy when the parties to a contract for the carriage of goods have chosen the court and the applicable legal regime to any future dispute arising out of the contract. ${ }^{19}$ This process is known as the denaturalisation of contracts.

9. The definition of services has not been clarified by the CJEU until the Corman-Collins ${ }^{20}$ judgment was issued. The Court clarified that the first criterion set out in the Falco case, namely the existence of an activity that requires the performance of positive acts, rather than mere omissions, and that the second criterion, namely the remuneration paid as consideration for an activity, is not to be understood strictly as the payment of a sum of money. ${ }^{21}$

10. The determination of the place of performance is subject to domestic law since there is no European definition, as held in the Tessili $v$ Dunlop case. ${ }^{22}$ In this case, the special jurisdiction was decided according to the lex fori rules of applicable law. This was the first example where the Court did not insist on an autonomous EU interpretation of a harmonised conflict of laws concept. The reference to domestic law implies determining whether a particular contract is one for the sale of goods or the provision of services. Transport contracts, whether maritime or multimodal, may be categorised under one category depending on the domestic law of the EU Member State in the absence of any harmonisation at the EU level. ${ }^{23}$ The place of performance of the obligation, the payment, is determined by national law according to the Tessili case. There is still no other autonomous EU interpretation and thus a harmonised place of performance formula outside the scope of Article 7(1)(b) of Brussels I Recast Regulation superseding the Tessili $v$ Dunlop judgment.

11. However, as in the latter case, the Advocate General in the Corman-Collins judgment held that the EU conflicts laws do not qualify contracts and identify their place of performance among the categories of Article 7(1)(b) of the Brussels I Recast Regulation, leaving its characterisation to national courts. Since the category of services fell within the precept in this case, the Court did not address this issue. When the Corman-Collins judgment was handed down, Article 5(1) of the Brussels I Regulation had already been amended to harmonise the place of performance of contracts for the sale of goods and provision of services. For these contracts, the place of performance of the obligation in question is settled, for instance, if the claim is based on the payment of a price. The connecting factor is the one arising out of the contract for all claims and not just those attached to the connecting factor itself. When the main place of delivery is unidentifiable by the court the claimant may choose sue the defendant at any of the courts where the goods were delivered. The question of whether the first indent of Article 7(1) (b) was applicable to more than one EU Member States or between an EU Member State and a non-EU Member State was left opened by the CJEU. ${ }^{24}$

${ }^{18}$ The standard maritime type-form contracts "developed by large private organisations such as the Baltic and International Maritime Council (BIMCO), the Independent Tanker Owners Association (INTERTANKO) or the International Association of Dry Cargo Ship owners (INTERCARGO) provide no legal certainty in material terms [...]. In the absence of a choice of law, a jurisdiction or arbitration agreement, separately from the law applicable to the charter party or the $\mathrm{B} / \mathrm{L}$, the court or arbitral tribunal can decide the applicable substantive law, as provided by institutional rules of many domestic laws;" J. ECHEBARRIA FERNÁNDEZ, "Limitations on jurisdiction and arbitration agreements based on applicable law and the identity of the carrier in cargo claim disputes: who and where to sue?", $C D T$, vol. 11, No. 1, 2019, pp. 306-321, at p. 312.

${ }_{19}$ The claimant may rely on the dispute resolution venue agreed in a contract for the carriage of goods by sea, the charter party $(\mathrm{C} / \mathrm{P})$, or "the Bill of Lading $(\mathrm{B} / \mathrm{L})$ may serve as evidence of the contract of carriage with the charterer or the shipowner depending on the law of the forum where a claimant, such as the shipper may bring a cargo claim;” J. ECHEBARRIA FERNÁNDEZ (note 18), at p. 317.

${ }^{20}$ Judgment of 19 December 2013, Corman-Collins SA v La Maison du Whisky SA, C-9/12, EU:C:2013:860.

${ }^{21} \mathrm{~N}$. ENONCHONG (note 12), at p. 203.

${ }_{22}^{2}$ Judgment of 6 October 1976, Industrie Tessili Italiana Como v Dunlop AG, C-12/76, EU:C:1976:133, paragraph 14.

${ }^{23}$ G. Van Calster, European Private International Law, Bloomsbury Publishing, 2016, pp. 140-144.

${ }^{24}$ T. C. HARTLEY, International Commercial Litigation: text, cases and materials on private international law, Cambridge University Press, 2015, p. 53. 
12. The choice of place of performance must comply with the requirements set out in current Article 7(1)(a) of Brussels I Recast Regulation, meaning that the parties' choice has to relate to a genuine place of performance. If the parties have agreed to a choice of court that meets the requirements of Article 25 of Brussels I Recast Regulation, that provides for more formal requirements, this will prevail over the less stringent forum requirements contained in Article 7. However, paragraph 4 of Les Gravières Rhénanes judgment ${ }^{25}$ prescribed that the parties are not entitled "to designate, with the sole aim of specifying the courts having jurisdiction, a place of performance having no real connection with the reality of the contract at which the obligations arising under the contract could not be performed in accordance with the terms of the contract".

13. Finally, the most important element to consider regarding a contract for the provision of services is the performance of a particular requested activity for remuneration. Article 7(1)(b) was drafted as a modification of the general rule of Article 7(1)(a) of the Brussels I Recast Regulation and leads to a creative interpretation of the latter concept. The CJEU proposed a narrower construction of Article 7(1) (b) in the Falco judgment defining it as an exception to the general rule of Article 7(1)(a) of the Brussels I Recast Regulation. As BRIGGS suggests, the court was right in ignoring its own doctrine settled in the Corman-Collins case, since there "is no obvious need for judicial wariness in relation to Article 7(1) (b) $[\ldots]$ The jurisdictional rule does not call into question one which should be protected from being overshadowed". ${ }^{26}$

\section{Distinction between contracts for the sale of goods and contracts for the provision of services including the carriage of goods by sea: The battle goes on}

14. One of the factors stressed by the CJEU in the Car Trim and Granarolo ${ }^{27}$ judgments to classify a contract as one for the provision of services or the sale of goods within the first indent of Article $7(1)$ is based on the characteristic performance. An autonomous assessment of the obligation that characterises the contract must be carried out by the court.

15. In the Car Trim judgment, ${ }^{28}$ the CJEU interpreted the provision of services or sale of goods under Article 7(1)(b) of the Brussels I Recast Regulation, stating that the classification must be based on the obligations that characterise the contract in question. The final destination of the goods ${ }^{29}$ was the preferred option chosen by the CJEU to determine for the place of performance, considering the close connection between the forum and the law applicable to the contract. In other words, instead of the transfer of legal title, the physical transfer or handover of the goods to the buyer or its agent is the crucial determinant of the place of performance, paying due regard to contractual terms and the general customs and usages ${ }^{30}$ related to trade. ${ }^{31}$

16. In any case, the judge has to resort on the applicable law to the contract in order to determine the place of performance of the obligation in question and to find special jurisdiction. In case of execution of the contract, the actual delivery location has priority over the agreed one. The autonomous interpretation of the CJEU has further developed how an EU Member State court must determine the place of performance. ${ }^{32}$

${ }^{25}$ Judgment of 20 February 1997, Mainschiffahrts - GenossenschafteG (MSG) v Les GravièresRhénanesSarl, C-106/95, EU:C:1997:70, paragraph 4 of the summary.

${ }^{26}$ A. BRigGs (note 7), at [2.715].

27 Judgment of 14 July 2016, Granarolo SpA v Ambrosi Emmi France SA, C-196/15, EU:C:2016:559.

28 Judgment of 24 September 2009, Car Trim GmbH v.KeySafety Systems Srl, C-381/08, EU:C:2010:90.

${ }^{29}$ Car Trim judgment, paragraph 60.

30 Judgment of 9 June 2011, Electrosteel Europe SA v Edil Centro SpA, C-87/10, EU:C:2011:375.

${ }^{31}$ A. Briggs (note 7), at [2.179].

${ }^{32}$ More precisely, the Rome I Regulation has done it to a wider extent with regard to the applicable law to civil and commercial contracts. The English version of Article 7 of the Brussels I Recast Regulation defines the "place of performance of the obligation in question" as the one of delivery of goods or provision of services in a Member State "under the contract". In 
17. According to VAN CALSTER, ${ }^{33}$ if the delivery does not take place at the consented to place but elsewhere and the defendant contests the jurisdiction, pursuant to Article 7(1)(c), the forum redirects to Article 7(1)(a), which refers "in matters relating to a contract, in the courts for the place of performance of the obligation in question".

18. The CJEU confirmed the correctness of the Tessili in the Concorde $e^{34}$ and Custom Made ${ }^{35}$ judgments regarding Article 7(1)(a) of the Brussels I Recast Regulation. ${ }^{36}$ The switch of paradigm from the applicable law to the contract to the place of delivery of goods or provision of services in order to determine the place of performance of the contract (and the court competent to hear the case) arrived after the Concorde judgment. ${ }^{37}$ On one hand, Article 7(1)(a) followed the previous criteria set out by the CJEU. On the other hand, the new Article 7(1)(b) of the Regulation introduces the changes following the grounds of the decision and the advice of the Advocate General in the Concorde case: ${ }^{38}$

"[...], for the purpose of the forum contractus, the court must presume that the place of performance of an obligation is the place where the obligation which characterises the legal relationship in question was performed or was to be performed."

19. Therefore, a uniform rule is applied if the place where the provision of services was provided is not identifiable in the contract. Such uniform rule displaces the criteria set out in the Tessili case without resorting to the applicable law to the contract. ${ }^{39}$

20. "A contract which has as its characteristic obligation the supply of a good will be classified as a 'sale of goods' within the meaning of the first indent" of Article 7(1)(b) of the Brussels I Recast Regulation. "A contract which has as its characteristic obligation the provision of services will be classified as a 'provision of services' within the meaning of the second indent" of Article 7(1)(b) of the Regulation..$^{40}$ The characteristic performance in the Granarolo and the Car Trim judgment was the supply of goods. The CJEU set out in the Granarolo case (concerning commercial distribution contracts) that such classification is applicable to: ${ }^{41}$

"[...] a long-term commercial relationship between two economic operators, where that relationship is limited to successive agreements, each having the object of the delivery and collection of goods.

case of divergence between the place of actual delivery of the goods or provision of services and the one agreed to between the parties, the French version of Article 7 seems to suggest that actual delivery or provision of services - or where they were supposed to be performed - takes precedence over the agreed place by the parties: "devant la juridiction du lieu d'exécution de l'obligation qui sert de base à la demande"; Vid. ad. ex.,I. Lorente MARTíneZ (note 13), pp. 225-232, where the author analyses the term "under contract".

${ }^{33}$ G. VAN CALSTER (note 23), pp. 140-144.

34 Judgment of 28 September 1999, GIE Groupe Concorde and Others v The Master of the vessel "Suhadiwarno Panjan" and Others, C-440/97, EU:C:1999:456.

35 Judgment of 29 June 1994, Custom Made Commercial Ltd v.StawaMetallbau GmbH, C-288/92, EU:C:1994:268.

${ }^{36}$ A. Briggs (note 7), at [2.178].

${ }^{37}$ For further information on the place of performance in contracts for the sale of goods or the delivery of services, vid. A. BorRÁs RodrígUEZ, "La competencia de los tribunales internos en materia de obligaciones contractuales (comentario a la sentencia del Tribunal de Justicia de las Comunidades Europeas de 15 de enero de 1987, asunto 266/85)", RIE, 1987, pp. 731-740. pp. 731-740); M. A. CeBrián SAlvat "Las operaciones contractuales complejas en Derecho Internacional Privado Europeo", Anuario español de Derecho internacional privado, 2017, pp. 333-378; I. LoRENTE MARTínEZ, "La fundamentación económica del foro especial en materia contractual contenido en el Artículo 7.1 B) Guión Primero del Reglamento Bruselas I bis", CDT, Vol. 8, No 2, 2016, pp. 278-291; Ibid., "Brexit y cláusulas de sumisión en los contratos internacionales", CDT, 2017, pp. 408-418; P. MANKOWSKI, "The role of party autonomy in the allocation of jurisdiction in contractual matters", in F. FERRARI and F. RAGNO (eds.), Cross-border litigation in Europe: the Brussels I Recast Regulation as a panacea?, Padova, CEDAM, 2015, pp. 97-125; A.-L. Calvo Caravaca and J. Carrascosa González, Derecho internacional privado, vol. II, Comares, 2016, pp. 838-862.

38 Opinion of Mr. Advocate General RuIz-Jarabo Colomer of 16 March 1999, GIE Groupe Concorde and Othes $v$ The Master of the vessel "Suhadiwarno Panjan" and Others, Case C-440/97, EU:C:1999:146, paragraph 103.

${ }^{39}$ A. Briggs (note 7), at [2.179].

${ }^{40}$ Granarolo case, at paragraph 35. The CJEU refers to the definition provided in the Car Trim judgment, paragraph 32.

${ }^{41}$ Granarolo case, at paragraph 36. 
However, it does not correspond to the general scheme of a typical distribution agreement, characterised by a framework agreement, the aim of which is an undertaking for supply and provision concluded for the future by two economic operators $[\ldots]$ ".

21. The CJEU prescribed in the Kareda $v$ Benko ${ }^{42}$ case that a commercial distribution contract superseded by a wider relationship between the parties where its main object is not just the supply of goods is not considered a contract for the sale of goods. ${ }^{43}$

\section{Place of performance as a ground of jurisdiction in contracts for the sale of goods and the pro- vision of services}

22. The EU Member State court where the delivery of goods or the provision of services can be ascertained from the facts of the case will have jurisdiction. A lawsuit can be distributed between different EU Member States. However, according to the Shenavai judgment, ${ }^{44}$ an accumulation of claims is possible when the judge determines the place of performance of a main obligation. ${ }^{45}$ The 'sound administration of justice' criterion was relevant to determine the place of performance of the obligation in the Concorde judgment. ${ }^{46}$

23. The place of performance should be determined according to the nature of the obligations and the proximity to the place of provision of services or where the goods are located. Recital 16 of the Brussels I Recast Regulation echoes the previous statement by setting out that "in addition to the defendant's domicile, there should be alternative grounds of jurisdiction based on a close connection between the court and the action or in order to facilitate the sound administration of justice. The existence of a close connection should ensure legal certainty and avoid the possibility of the defendant being sued in a court of a Member State which he could not reasonably have foreseen." ${ }^{47}$

24. First, if there are varied obligations with equal importance the national judge will have to assess its competence only in respect of the obligations to be performed within its national territory lea-

${ }^{42}$ Judgment of 15 June 2017, Saale Kareda v Stefan Benkö, C-249/16, EU:C:2017:472. The case involved a loan repayment to a bank between two parties for the purchase of an apartment in Austria.

${ }^{43}$ I. Antón Jú́REZ, "The Challenges of the Transnational Litigation in the European Union: Has the Notion of Matters Relating to a Contract Been Extended Too Much in Brussels I Regulation", CDT, vol.10, no. 1, 2018, p. 530.

${ }^{44}$ See for instance, the judgment of 15 January 1987, Hassan Shenavai $v$ Klaus Kreischer, C-266/85, EU:C:1987:11, concerning the claim over the fees due to a German architect by a Dutch customer before the German court. The case follows the judgment of 6 October 1976, A. De Bloos, SPRL v Société en commandite par actions Bouyer, C-14/76, EU:C:1976:134. The latter case concerns a claim for the infringement of an exclusive sales concession by the grantor the obligation of the current Article 7(1) of the Brussels I Recast Regulation was defined as "the contractual obligation forming the basis of the legal proceedings $[\ldots]$ which arises under the contract and the non-performance of which is relied upon to support such claims." The CJEU departed from the traditional interpretation and set out a restricted previous doctrine for employment contracts in the judgment of 26 May 1982, Roger Ivenel v Helmut Schwab, C-133/81, EU:C:1982:199. The CJEU defined the obligation of Article 7(1) of the Brussels I Recast Regulation as the one that should be analysed in order to determine the place of performance of the contract, providing jurisdiction to courts where the employee was obliged to perform his obligations. The judgment superseded the previous interpretation under which the employer's court would have jurisdiction to hear the case since the payment to the employee was the basis of the claim for the non-performed contractual obligation; in U. MAGNUS and P. MANKOwSKI (eds.), European Commentaries on Private International Law. Brussels I Regulation, $2^{\text {nd }}$ ed., Otto Schmidt, revised ed., 2011, p. 400; U. Gruší, The European Private International Law of Employment, Cambridge University Press, 2015, pp. 96-98.

45 A.-L. Calvo Caravaca and J. Carrascosa González (note 37), p. 861.

${ }^{46}$ The case in its paragraph 31 provides that: "It is for the national legislature, which has exclusive competence in this field, to define a place of performance which takes fairly into account both the interest of sound administration of justice and the interests of adequate protection for individuals. It may well be that in so far as national law allows, the national court will have to determine the place of performance by reference to the criteria suggested by the referring court - i.e. by identifying, by reference to the obligations undertaken and the circumstances of the case, the place where the thing or service contracted for was, or should have been, provided."

47 "This is important, particularly in disputes concerning non-contractual obligations arising out of violations of privacy and rights relating to personality, including defamation" such as the eDate Advertising case).Judgment of 25 October 2011, eDate Advertising GmbH v X and Olivier Martinez, Robert Martinez and MGN Limited, C-509/09 and C-161/10, EU:C:2011:685 will be analysed in section III (Non-contractual actions under Article 7(2) of the Brussels I Recast Regulation. 
ding to multiple proceedings. ${ }^{48}$ The CJEU followed the latter approach in the Leathertex case, ${ }^{49}$ where two obligations were considered of equal importance by the CJEU..$^{50}$

25. Second, if such place is located in a non-EU Member State Article 7(1)(b) of the Brussels I Recast Regulation will not be applicable. Third, if the main place of delivery or provision of services cannot be still detected, the court of any EU Member State where one of the deliveries of goods or provision of services takes place will have jurisdiction to hear the case. The delivery of goods or provision of services within numerous or indefinite States poses major problems in identifying the court to which jurisdiction may be allocated. ${ }^{51}$ A list of EU Member State and non-EU Member State places of performance was provided without a definite geographic limit of such places of performance in the Besix judgment. ${ }^{52}$

26. The current Article 7(1)(a) of the Brussels I Recast Regulation was not applicable to the Mora Shipping case, ${ }^{53}$ where the court found that there was no forum agreement determining the place of performance (i.e. the place of payment of the contributions as a result of general average). Mora Shipping SA, the claimant, was incorporated in Liberia and domiciled in Liberia and/or Norway while the cargo insurers, the defendants, were domiciled in France, Belgium, the United Kingdom (hereinafter UK) and Switzerland. The express terms of the average guarantee provided that cargo insurers had to pay to the "shipowners or to the Average Adjusters" and the High Court upheld the Court of Appeal's decision by dismissing the appeal..$^{54}$

27. The case followed previous English case law such as The Atlas Pride, ${ }^{55}$ where the Court of Appeal of England and Wales considered the borrower as the characteristic performer, i.e. the party that normally performs "certain rights and duties forming the contract, which are normally those requiring a non-pecuniary performance" in onerous contracts. ${ }^{56}$ The principle "is no more specific than any of those principles it is intended to supersede (proper law, seat of the relationship between the parties, place of performance, closest connection and hypothetical intention). The different categories shall be established by ascertaining for each of them" the specific characteristic obligation. ${ }^{57}$ However, it remains unclear if the borrower or the lender is the characteristic performer according to the CJEU case law while the Rome I Regulation does not provide a definition of habitual residence for natural persons ${ }^{58}$ beyond Article 19 that defines the habitual residence of legal entities as the place where a branch, agency or any other establishment is located.

${ }^{48}$ M. A. Cebrián Salvat, "The Spanish Rules of Residual Jurisdiction in Matters Related to Contract”, CDT, vol. 9, no. 2, 2017, pp. 143-144.

49 Judgment of 5 October 1999, Leathertex Divisione Sintetici SpA v Bodetex BVBA, C-420/97, EU:C:1999:483.

${ }^{50}$ A. Briggs (note 7), at [2.177].

${ }^{51}$ A.-L. Calvo Caravaca and J. Carrascosa González (note 37), p. 858.

52 Judgment of 19 February 2002, Besix SA v Wasserreinigungsbau Alfred Kretzschmar GmbH \& Co. KG (WABAG) and Planungs- und ForschungsgesellschaftDipl. Ing. W. Kretzschmar GmbH \& KG (Plafog), C-265/00, EU:C:2002:99.

${ }_{53}$ Judgment of the Court of Appeal of England and Wales (Civil Division) of 28 July 2005, Mora Shipping Inc v Axa Corporate Solutions Assurance SA and others, [2005] EWCA Civ 1069, 2 Lloyd's Rep 769.

${ }^{54}$ A. Briggs (note 7), at [2.182].

${ }^{55}$ A Greek shipowner resident in the United States since 1995 advanced payments for salvage operations to a Greek salvage group. The day after the Greek shipowner instituted proceedings in England for repayment of the disbursed amounts the defendant started proceedings in Greece. The Greek shipowner did not appear at court in Greece and was not notified in about the proceedings in his new address but in London where he ceased to reside in 1992. The Court of Appeal did not recognise and enforce the Greek judgment since the defendant "was not given the opportunity to defend himself at the hearing by being notified of the proceedings" according to Article 34(2) of the Brussels I Regulation; Judgment of the Court of Appeal of England and Wales (Civil Division) of 9 March 2006, Tavoulareas $v$ Alexander G Tsavliris \& Sons Maritime Co (The Atlas Pride) (No 2) [2005] EWHC 2643 (Comm); [2006] 1 All ER (Comm) 130; See A. Briggs (note 7), at [5.22].

${ }^{56}$ F. VISCHER, "The Principle of the typical performance in International contracts and the draft Convention," in K. LIPSTEIN (ed.), Harmonization of Private International Law by the EEC, University of London, 1978, pp. 25-30, at p. 27.

${ }^{57}$ K. Lipstein, "Characteristic Performance - A New Concept in the Conflict of Laws in Matters of Contract for the EEC", Northwestern Journal of International Law and Business, 1981, no. 3, pp. 402-414, at p. 409.

${ }_{58}$ P. Stone, EU private international law, Edward Elgar Publishing, 2014, pp. 308-309. 


\section{A particular case: multiple places of performance with special regard to multimodal transport}

28. When the delivery of goods or provision of services takes place in the same EU Member State according to the contract, jurisdiction is allocated to the court where of the main delivery of goods or provision of services. If such place cannot be identified any of those courts may have special jurisdiction $^{59}$ following the Color Drack ${ }^{60}$ or the High Court of England and Wales' Canyon Offshore ${ }^{61}$ cases.

29. In the Color Drack case, the CJEU held, concerning special jurisdiction, that in case of multiple places of delivery in the same EU Member State, a close linking factor is required between the contract and the court hearing the case in order to ensure an efficient organisation of the proceedings. As there were different places of delivery in that case, the national court had to determine the main place of delivery by resorting on pecuniary criteria. If there was no principal place of delivery, a claimant would have the possibility of suing the defendant in the court of any place of delivery. The chosen court will then hear all issues connected with the contract by applying Article 7(1)(b) of the Brussels I Recast Regulation. However, if the place of principal delivery cannot be determined and there is only a partial special jurisdiction, the court seized will avoid this problem by finding a main place of delivery or the place of the main obligation if there is more than one.

30. The High Court of England \& Wales' Canyon Offshore ${ }^{62}$ case shows the limitations and problems of the rule in Article 7(1) of the Brussels I Recast Regulation since the claimant was allowed to choose between starting proceedings in England or Scotland. ${ }^{63}$ "If the advantages gained by the party performing the activity have an economic value that may be regarded as constituting remuneration" ${ }^{64}$ There are two criteria to be fulfilled as laid down in the decisions of the CJEU: one party as the seller and shipper carries out a number of activities the involve the performance of positive acts, including the transport of goods, in return for remuneration by performing such acts. In the current case, the issuing bank performed a series of activities that constituted "the performance of positive acts" in exchange for a commission. ENONCHONG disagrees with the CJEU's requirement that contractual counterpart (the beneficiary) must pay the remuneration, since the instructing bank is the one that provides for it. However, "it is submitted that it is not a requirement $[\ldots]$ that the remuneration be provided by the other contracting party for a contract to be classified as one for the provision of services". The remuneration should be transferred by the other contracting party ${ }^{65}$ since this would be contrary to the "commercial reality" and "the broad approach adopted by the CJEU" ${ }^{\prime 6}$ in its case law. ${ }^{67}$ The court with special jurisdiction will be the single place where the goods have been delivered. When the judge cannot determine such place, the claimant may start proceedings in any of the multiple places of performance if they are located in one EU Member State.

31. All in all, Article 7(1)(b) of the Brussels I Recast Regulation will not be applicable if the parties submit any future dispute to a concrete forum or when the analytical-distributive method $^{68}$ is not

\footnotetext{
59 A.-L. Calvo Caravaca and J. Carrascosa González (note 37), p. 859.

60 Judgment of 3 May 2007, Color Drack GmbH v Lexx International Vertriebs GmbH, C-386/05, EU:C:2007:262.

${ }^{61}$ The English and Scottish courts had special jurisdiction since the obligation could be performed both in England or Scotland in the Canyon Offshore case, op. cit. note 41, [2014] EWHC 3810 (Comm) case; A. BRIGGS (note 7), at [2.182].

${ }^{62}$ Judgment of the England and Wales High Court (Commercial Court) of 27 November 2014, Canyon Offshore Ltd v GDF Suez E\&P Nederland BV [2014] EWHC 3810 (Comm).

${ }^{63}$ G. VAN CALSTER (note 23), pp. 140-144.

${ }^{64}$ N. ENONCHONG (note 12), at p. 203.

${ }^{65}$ Regarding the English contractual law requirement of 'consideration', see e.g., the judgment of the England and Wales High Court of 5 February 1842, Thomas $v$ Thomas [1842] 2 QB 851, 859, and the judgment of 7 June 1861, Tweddle v Atkinson [1861] 1 B \& S 393, 398; 121 ER 762.

${ }^{66}$ N. ENONCHONG (note 12), at p. 203.

${ }^{67}$ Especially in the Corman-Collins $S A$ case.

${ }^{68}$ The analytical-distribute method follows the "direct solutions" contained in Article 7(1) of the Brussels I Recast Regulation according to the applicable law of the contract (normally designated by the 'conflict rules' of the court's Private International Law) in order to ascertain the place of execution of the allegedly unfulfilled obligation; the parties' freedom of will to designate a concrete forum to solve any future dispute; and the place of performance of the main obligation where all
} 
applicable to contracts that are neither sale of goods nor provision of services (as stated in the Brogsitter case). ${ }^{69}$ Moreover, Article 7(1)(b) is not applicable when the parties agree that the delivery of goods or delivery of services are in a non-EU Member State. ${ }^{70}$

32. How should a national EU Member State judge ascertain a single place of delivery of the goods or the provision of services if they are located in multiple EU Member States? It is "arguable, if not yet completely clear, that the claimant may sue in any one of those EU Member States in relation to the whole of the delivery". ${ }^{71}$ However, this would lead to multiple proceedings in the 28 EU Member States and the 4 European Free Trade Association (EFTA) Member States where the Lugano Convention is applicable.

33. When there is a sufficient link between more than one EU Member State and the main place of delivery or provision of services does not correspond to a single EU Member State court, the CJEU's case law allocates jurisdiction to any of those courts as shown in the Rehder case. ${ }^{72}$ In this case, involving a passenger's claim against an airline, the court took a pragmatic approach after ruling out the possibility of applying the 'centre of gravity' approach. ${ }^{73}$ The contract provided for two 'centres of gravity', the place of embarkation and disembarkation, and the CJEU left the option of where to start proceedings between the two places at the claimant's choice. Such choice is applicable to the provision of services including the carriage of goods between two different EU Member State courts. ${ }^{74}$ The buyers can start proceedings at the courts of the seller's domicile or where the goods have been delivered, which are normally the buyer's place of business. ${ }^{75}$

34. Multimodal transportation has been an object of analysis by the CJEU case law. The absence of uniform international instruments ${ }^{76}$ containing rules for jurisdiction and applicable law regarding multimodal transport has reinforced the vis attractiva of the Brussels I Recast Regulation and the Rome I and II Regulations. No international instrument related to multimodal transportation would be applicable with preference over the general EU law instruments under the so-called 'rule of specialty' (lex specialis derogat legi generali $)^{77}$ is in force.

the secondary claims may be accumulated. The analytical-distributive method is not applicable when the obligation has to be complied in multiple places, lacks of a place of execution or in case of biased use of Article 7(1)(a) by judges leading to an abusive application of national law.

${ }^{69}$ Judgment of 13 March 2014, Marc Brogsitter v Fabrication de Montres Normandes EURL and Karsten Fräßdorf, C-548/12, EU:C:2014:148.

70 A.-L. Calvo Caravaca and J. Carrascosa González (note 37), pp. 860, 861, and 863.

${ }^{71}$ A. Briggs (note 7), at [2.181].

72 Judgment of 9 July 2009, Peter Rehder v Air Baltic Corporation, C-204/08, EU:C:2009:439.

73 The CJEU provides for the 'centre of gravity' approach in default of the following criteria set out in the Wood Floor Solutions Judgment of 11 March 2010, Wood Floor Solutions Andreas Domberger GmbH v Silva Trade SA, C-19/09, EU:C:2010:137 case concerning commercial agency contracts in which services were provided in various EU Member States. The CJEU applied the same presumption of Article 7 of the Brussels I Recast Regulation and guided the domestic court as to the location of the place of performance. The CJEU has ranked the criteria to be followed by EU courts in order to determine the place of performance starting by the single place of provision, followed by the place where the service provider (e.g. a commercial agent) has its domicile and finally, by resorting on the place where the duties related to an employment took place. The CJEU follows the requirements set out in the judgment of 13 July 1993, Mulox IBC Ltd v Hendrick Geels, C-125/92, EU:C:1993:306, and the judgment of 9 January 1997, Petrus Wilhelmus Rutten v Cross Medical Ltd, C-383/95, EU:C:1997:7.

${ }^{74}$ A. Briggs (note 7), at [2.180].

75 T. C. HartLey (note 24), p. 61.

${ }^{76}$ For instance, the following Conventions are still not in force: the United Nations Convention on International Multimodal Transport of Goods ("Multimodal Convention") of 24 May 1980, U.N. Doc. TD/MT/CONF/17; and the 2008 Convention on Contracts for the International Carriage of Goods Wholly or Partly by Sea ("Rotterdam Rules") of 11 December 2008. The final text of the Convention is annexed to General Assembly Resolution 63/122, U.N. Doc. A/RES/63/122.

${ }^{77}$ See Article 71 of the Brussels I Recast Regulation, Article 25 of the Rome I Regulation and Article 28 of the Rome II Regulation. The rule of specialty makes applicable certain specialised maritime Conventions containing jurisdiction provisions prevalent over the Regulation following Article 57 of the Convention of 27 September 1968 on jurisdiction and the enforcement of judgments in civil and commercial matters OJ 1972, L 299/32, consolidated text of 26 January 1998 [1998] OJ 1998 C 27/1 (Brussels Convention); Vid. J. EchebarRia Fernández (note 18), at p. 309. However, this article does not tackle in depth the 
35. The latest CJEU's case law development related to the subject matter is found in the Zurich Insurance case. ${ }^{78}$ The most striking factor that entails a limitation to party autonomy is found in the Opinion of the Advocate General TANCHEV, where "it is for the national courts to decide whether a dispute falls within the scope of the $\mathrm{CMR}^{79}$ (in case of transport of goods by land), and, in the present case, the [...] Court of Appeal [of] Vaasa held that the CMR was not applicable ratione materiae because the case entails combined transport" ${ }^{80}$ Any submission agreement to a specific court contained in a contract for the carriage of goods by road or by sea may not be enforceable in case of multimodal transport. The 'rule of specialty' operates by giving force to the international Conventions that stipulate the possibility of the parties' agreeing on non-exclusive or exclusive agreements. ${ }^{81}$ However, when an exclusive jurisdiction agreement pursuant to Article 25 of the Brussels I Recast Regulation is not included in the contract for the provision of services in case of multimodal transport, the court having jurisdiction will be the one of the "place where a service is provided in connection with a contract for the carriage of goods".

36. The Finnish Supreme Court referred the following question to the CJEU for preliminary ruling: 'How are the place or places where the service is provided to be determined in accordance with the second indent of Article 5(1)(b) of Council Regulation (EC) No 44/2001 in a case involving a contract for the carriage of goods between Member States in which the goods are conveyed in several stages and by different means of transport?' ${ }^{82}$ The CJEU held that "the place in a Member State where, under the contract, the services were provided or should have been provided" under the second indent of Article 7(1)(b) of the Brussels I Recast Regulation (in case of services provided in different EU Member States) is understood "as the place with the closest linking factor between the contract and the court having jurisdiction, which, as a general rule, will be at the place of the main provision of services". ${ }^{83}$

liability regime set out by "the conventions to which the Member State are parties and which, in relation to particular matters, govern jurisdiction or the recognition or enforcement of judgments" according to Article 71 of the Brussels I Recast Regulation. The Hague-Visby Rules, The International Convention for the Unification of Certain Rules of Law Relating to Bills of Lading signed at Brussels on 25 August 1924, 'the Hague Rules', 51 Stat 223, 120 LNTS 155, amended by the Protocol to Amend the International Convention for the Unification of Certain Rules of Law Relating to Bills of Lading signed at Brussels on 23 February 1968, 'the Visby rules', 1412 UNTS 121, and the last Protocol amending the Hague-Visby Rules signed in Brussels on 21 December 1979 ('SDR Visby Protocol' switching from franc Poincaré (gold) to Special Drawing Rights of the International Monetary Fund) UNTS 146, are mandatorily applicable where enacted. These Rules are only applicable to a B/L but not a charter party $(\mathrm{C} / \mathrm{P})$. They regulate the liability regime in case of cargo claim. International maritime Conventions also offer limitations in their territorial scope of application. Some Member States (Romania, Hungary, Czech Republic and Austria) are parties to international Conventions such as the Hamburg Rules (The United Nations Convention on the Carriage of Goods by Sea approved in Hamburg, 30 March 1978 that entered into force on 1 November 1992) while most are not.

78 Judgment of the 11 July 2018, Zurich Insurance plc and Metso Minerals Oy v Abnormal Load Services (International) Ltd, C-88/17, EU:C:2018:558.

${ }^{79}$ Convention of 19 May 1956 on the Contract for the International Carriage of Goods by Road (CMR), 399 UNTS 189 CMR.

${ }^{80}$ Opinion of the Advocate General TANCHEV delivered on 10 April 2018 prior to the Zurich Insurance judgment, C-88/17, EU:C:2018:224, at paragraph 25. Moreover, the Advocate General SAUgmandsGaArd ØE, in his Opinion of 20 June 2019 regarding the case Adriano Guaitoli and Others v easyJet Airline Co. Ltd, C-213/18, EU:C:2019:524 (an analogous case involving the carriage of passengers by air) highlights at paragraph 43 that "since the rights based respectively on the provisions of Regulation No 261/2004 and of the Montreal Convention (Convention for the Unification of Certain Rules for International Carriage by Air of 28 May 1999) fall within different regulatory frameworks, the rules on international jurisdiction provided for in that Convention do not apply to applications made on the basis of Regulation No 261/2004 alone, which must be examined in the light of Regulation No 44/2001." The Advocate General refers to paragraph 46 of the judgment of 10 March 2016, Flight Refund Ltd v Deutsche Lufthansa AG, C-94/14, EU:C:2016:148, and paragraphs 27 and 28 of the Rehder judgment.

${ }^{81}$ The Hague-Visby Rules do not provide for jurisdiction or arbitration rules. The international maritime Conventions set out a variety of possibilities to initiate proceedings but do not include exclusive jurisdiction clauses.

Articles 21 and 22 of the Hamburg Rules contain jurisdiction and arbitration rules, respectively. The still not in force Rotterdam Rules (only Spain has ratified within the EU) will allow exclusive jurisdiction and arbitration agreements (Articles 67 and 72, respectively) but strictly for volume contracts that fulfil the requirements of Article 80 ('Special rules for volume contracts'). In the absence of an exclusive agreement, the defendant has the possibility to choose between the seats prescribed by Articles 66 ('Actions against the carrier') or 68 ('Actions against the maritime performing party'). Among the Conventions presented above, only the Hamburg Rules may override the jurisdictional rules contained in Brussels I Recast Regulation.

${ }^{82}$ Paragraph 13 of the Zurich Insurance case.

${ }^{83}$ Zurich Insurance judgment at paragraph 16 referring to the Wood Floor case at paragraph 40. 
37. The relevant doctrine of the Rehder case is transposable to this case where goods were transported from Finland to the UK by lorry and ship. The relevant places to consider are the place of departure where the goods are dispatched by the consignor to the haulier and the place of destination where the goods have to arrive in perfect condition and in time, excluding "places where there is a lack of a 'sufficient link to the essential nature of the services resulting from [the relevant] contract", ${ }^{84}$ i.e. the intermediate stops in between. The contract for the provision of services is incardinated in the second indent of Article 7(1)(b) of the Brussels I Recast Regulation and encompasses different means of transport between EU Member States, "in several stages, with stops". "Both the place of dispatch and the place of delivery of the goods constitute places where transport services are provided [...]". ${ }^{85}$

\section{Place of performance, INCOTERMS and contracts for the sale of goods}

38. The International Chamber of Commerce's INCOTERMS establish a number of pre-defined contractual obligations. They constitute part of the 'lex mercatoria'. The role of the INCOTERMs or terms of sale has been reduced to avoid contractual segmentation into a bundle of contracts. In the UK and other Common law jurisdictions it constitutes a choice of law. However, for the European continental law and the Rome I Regulation it does not. ${ }^{86}$ The INCOTERMs have not been always accepted by the CJEU as a valid agreement for 'place of performance' within the meaning of Article 7 of the Brussels I Recast Regulation.

39. In the Rhoonse Recycling case, ${ }^{87}$ the CPT ("Carriage Paid To") InCOTERM was interpreted by the CJEU as referencing costs and not the place of delivery. In addition, in the Cimtrode case, ${ }^{88}$ concerning an Ex Works (EXW) INCOTERM as part of the contractual agreement, the court determined that it should be interpreted in accordance with the lex causae. A verbal agreement was not deemed to form part of the contract when it was not confirmed in writing but was a later reference to standard terms and conditions on invoices sent during the execution of the agreement as a confirmation of a jurisdiction agreement. ${ }^{89}$ This does not mean that the CJEU underestimates the relevance of INCOTERMS, as suggested in the Electrosteel case: ${ }^{90}$

"In order to verify whether the place of delivery is determined 'under the contract', the national court seized must take account of all the relevant terms and clauses of that contract which are capable of clearly identifying that place, including terms and clauses which are generally recognised and applied through the usages of international trade or commerce, such as the Incoterms drawn up by the International Chamber of Commerce [...]. If it is impossible to determine the place of delivery on that basis, without referring to the substantive law applicable to the contract, the place of delivery is the place where the physical transfer of the goods took place, as a result of which the purchaser obtained, or should have obtained, actual power of disposal over those goods at the final destination of the sales transaction".

40. The parties agree on the place of delivery of goods according to Article 7(1)(b) of the Brussels I Recast Regulation that serves to determine jurisdiction. However, in case of no agreement, Article $7(1)$ (a) is applicable and the judge will apply the law applicable to the contract to determine the place of compliance with the obligation that serves as the basis for the claim. As it has been recalled from the CJEU's case law, the characteristic performance under the contract and not the litigious obligation are taken into consideration to determine the competent court. ${ }^{91}$ The court of the place of the State where

${ }^{84}$ Opinion of the Advocate General TANCHEV delivered on 10 April 2018 prior to the Zurich Insurance judgment, C-88/17, EU:C:2018:224, at paragraphs 50-53 referring to paragraph 33 of the Wood Floor case.

${ }^{85}$ Zurich Insurance case at paragraph 25.

86 J. EcheBARRia FernándeZ (note 18), at pp. 312-313.

${ }^{87}$ Judgment of the Court of Rotterdam of 15 July 2015,Rhoonse Recycling \& Service BV v BSS Heavy Machinery GmbH, C/10/473788 / HA ZA 15-350, NL: RBROT: 2015: 5292.

${ }_{88}$ Judgment of the Dutch Court of Appeal (Hertogenbosch) of 1 September 2015, Cimtrode The Electrode Company GmbH $v$ Carbide BV, HD 200.133.747 / 01, NL:GHSHE [2015] 3396.

${ }^{89}$ G. VAN Calster (note 23), pp. 140-144.

${ }^{90}$ See the Electrosteel case, paragraph 26, concerns Ex Works (EXW) InCOTERMS.

${ }^{91}$ H. Gaudemet-Tallon, Compétence et execution des jugements en Europe. Règlement $n^{\circ}$ 44/2001, Conventions de 
the goods have been delivered or must be delivered is competent to hear all the disputes arising from the contract for the international sale of goods, regardless of the unfulfilled obligation. ${ }^{92}$ However, the CJEU did not follow the Tessili doctrine in the Electrosteel case where the judge had to find the applicable law according to its conflict of laws rules and the material place of performance of the contract according to the lex contractus. ${ }^{93}$

41. It shall be noted that the United Nations Convention on Contracts for the International Sale of Goods (hereinafter CISG) ${ }^{94}$ prevails over the Rome I Regulation as the special international instrument to determine certain "applicable substantive or material rules" to contracts for the international sale of goods. The Rome I Regulation serves as a conflict norm in order to determine the issues out of the scope of the CISG such as the existence or validity of the contract or procedural matters.

42. Parties are free to choose the applicable law to their contract according to Article 3 of the Rome I Regulation and in the absence of that agreement, the law of the habitual residence of the seller is the applicable one according to Article 4(1)(a) of the Rome I Regulation. However, the CISG prevails over the Rome I Regulation ${ }^{95}$ in determining certain substantive laws applicable to the contract for sale of goods (under the lex specialis derogat legi generali principle) when the parties have their place of business in different Contracting States according to Article 1(1)(a) of the CISG or "when the rules of private international law lead to the application of the law of a Contracting State" under Article 1(1) (b) of the CISG. In fact, the CISG does not point to the applicable law, but only to some "applicable substantive rules". The drawn distinction is important since every contract has its regulatory law and the application of the CISG it does not undermine that assumption.

43. Article 6 of the CISG allows the contracting parties to totally or partially exclude the application of the CISG. The matters not expressly settled by the CISG shall be governed "in conformity with the law applicable by virtue of the rules of private international law" ex Article 7(2) of the CISG. Article 31(a) of the CISG sets out a harmonised solution for contracts of sale involving the carriage of goods in line with international trade:

"If the seller is not bound to deliver the goods at any other particular place, his obligation to deliver consists:

(a) if the contract of sale involves carriage of the goods - in handing the goods over to the first carrier for transmission to the buyer;"

44. Article 9 of the CISG makes the INCOTERMS applicable with prevalence to the CISG since the "parties are bound by any usage to which they have agreed", the "practices which they have established between themselves", or any "usage of which the parties knew or ought to have known" in the type of international trade concerned. ${ }^{96}$ However, an EU Member State court's judge must interpret the trade

Bruxelles et de Lugano, $3^{\text {rd }}$ ed., LGDJ, 2002, p. 198; V. Heuzé AND P. MAYer, Droit international privé, $8^{\text {th }}$ ed., Montchrestein, 2004, p. 339.

92 C. M. RadtKe, "Le juge du lieu de livraison", Revue Lamy droit des affaires, no. 64, 2011, pp. 63-65, at p. 63; see the CJEU's case law in the Color Drack, Rehder and Car Trim judgments.

${ }^{93}$ C. Bruneau, "Les règles européennes de compétence en matière civile et commerciale. Règl. Cons. CE no 44/2001, 22 déc. 2000", JCP, vol. I, 2001, no. 11, pp. 533-541, in E. CASTELLAnos RuIz, "El valor de los Incoterms para precisar el juez del lugar de entrega", $C D T$, vol. 4, 2012, no. 2, pp. 93-122, at pp. 95-96.

${ }^{94}$ United Nations Convention on Contracts for the International Sale of Goods (CISG), adopted in Vienna on 11 April 1980, 1489 UNTS 3, 19 ILM.

${ }^{95}$ Article 90 of the CISG states that the convention does not preclude the application of any other international instrument "which contains provisions concerning the matters governed by this Convention, provided that the parties have their places of business in States parties to such agreement". Moreover, Article 25 of the Rome I Regulation and Article 28 of the Rome II Regulation allow for the application of the specialised CISG convention on the international sale of goods setting out that the Regulations "shall not prejudice the application of international conventions to which one or more Member States are parties at the time when this Regulation is adopted and which lay down conflict-of-law rules relating to" "contractual" and "non-contractual obligations".

96 Vid. E. Castellanos Ruiz (note 93), at pp. 97-99. 
customs and usages when ascertaining the place of delivery of the cargo according to Article 7(1)(b) of the Brussels I Regulation. Article 25 of the Brussels I Recast Regulation presupposes their contractual validity, which is determined by the applicable law. ${ }^{97}$ The INCOTERMS constitute an expression of the freedom of will of the parties and shall be consistently interpreted in relation to Article 7(1)(b) that points to the place where the goods are delivered "under the contract" ${ }^{98}$ However, CASTEllanos Ruiz points out that it would have been preferable that the CJEU followed Article 9(2) of the CISG where "the parties are considered, unless otherwise agreed, to have impliedly made applicable to their contract or its formation a usage that the parties knew or ought to have known and which in international trade is widely known and regularly observed by the parties to the type of contracts in the particular trade concerned". 99

45. Nevertheless, the CJEU disagreed with the possibility of relying on the applicable law in order to determine the place of delivery of the goods according to Article 7(1)(b) of the Brussels I Recast Regulation. ${ }^{100}$ Paragraph 22 of the Electrosteel judgment set out that:

"[...] in order to determine [...] the place of delivery" the national court "must take into account all the relevant terms and clauses in that contract, including [...] the terms and clauses generally recognised and applied in international commercial usage, such as the Incoterms, in so far as they enable that place to be clearly identified".

46. According to paragraph 40 of the Opinion of the Advocate General Kокотт delivered on 3 March 2011 (EU:C:2011:116) regarding the Electrosteel case: "The Ex Works clause would also be readily capable of determining the place of delivery because it describes not only the transfer of risk [...], but also the place of delivery [...] in the sense that it is a pure collection term. [...] The place of delivery and performance within the meaning of Article 5(1)(b) of Regulation No 44/2001 can be determined by the 'Ex Works InCOTERM' effectively incorporated into the contract $[\ldots]$ ". ${ }^{101}$

47. The CJEU makes a controversial statement when it confirms that the parties can freely agree on the place of delivery, provided that this place of delivery can be inferred from the contract "without reference to the substantive law applicable to the contract". ${ }^{102}$ "The 'Ex Works" clause would also be readily capable of determining the place of delivery because it describes not only the transfer of risk [...], but also the place of delivery [...] in the sense that it is a pure collection term". ${ }^{103}$ The principle of "pragmatic determination of the place of enforcement" under which the purchaser receives the physical possession of the transferred goods is applicable only in the absence of an agreement on the place of delivery. ${ }^{104}$

48. Courts have to make reference to all relevant terms and conditions in an agreement in order to determine the place of delivery under the first indent of Article 7(1)(b) of the Brussels I Recast Regulation. The defendant in the Granarolo case alleged that the 'Ex Works InCOTERM' included in the invoices should be taken into account when designating the place of delivery of the goods. ${ }^{105}$ The CJEU confirmed that: ${ }^{106}$

${ }^{97}$ G. Kaufmann-Kohler, La clause d'election de for dans les contrats internationaux, Bâle, 1980; Magnus, "Article 23 Brussels I" in U. Magnus and P. ManKowsKi (note 44), pp. 436-514.

98 Vid. C. M. RADTKE (note 92), at p. 63.

99 Vid. E. Castellanos Ruiz (note 93), at pp 95-96.

${ }^{100}$ See the criticism offered by D. MARTEL, "Le rôle des usages commerciaux internationaux dans la détermination du lieu de livraison des marchandises", La Semaine Juridique - édition générale, 2011, no 38, 2011, pp. 1659-1662, at p. 1661; in E. Castellanos Ruiz (note 93), at p. 117.

${ }^{101}$ C. SILVESTRI, "Ancora sul forum contractus nel Reg. n.44/2001: il valore delle previsioni contrattuali e delle clausole d'uso del commercio internazionale nell'individuazione del "luogo di consegna" ai sensi dell'art. 5, n. 1, lett.b)", Int'l Lis, 2011, pp. 127-130.

${ }_{102}$ Paragraph 16 of the Electrosteel judgment referring to paragraph 55 of the Car Trim case.

${ }^{103}$ Paragraph 40 of the Electrosteel case.

${ }^{104}$ Ibid., paragraphs 47 and 48.

${ }^{105}$ I. ANTÓN JuÁREZ (note 43), pp. 530.

${ }^{106}$ Granarolo case, paragraph 36. 
"[...] If any contract concluded orally or tacitly were classified as a contract for the sale of goods, the referring court would then have the task of ascertaining whether the indication 'Ex works' $[\ldots]$ does in fact appear systematically in the successive contracts between the parties. If that is the case, the goods will have to be regarded as delivered at Granarolo's plant in Italy and not in France, at Ambrosi's seat".

49. The CJEU stresses the importance of the INCOTERMS and enhances party autonomy by allowing the choice of a clear and precise place of delivery of goods taking all the contract clauses into consideration. The Electrosteel judgment overcomes the limitations found in the Car Trim case by allowing the judge determining the place of delivery of the goods for the purposes of determining the jurisdiction of the court where the goods are delivered, according to Article 7(1)(b) of the Brussels I Recast Regulation. However, the substantive law of the EU Member State cannot serve to determine the place where the goods have been delivered in the absence of an INCOTERM. The CISG is applicable to all EU Member States excluding the UK, Ireland, Portugal and Malta.

50. Without further reference to the substantive law applicable to the contract, according to the CJEU, the key element to be considered is where the physical transfer of the goods took place, as the purchaser obtained or should have obtained the actual power to dispose of the goods at the final destination of the sales transaction. The CISG or the Rome I Regulation is not applicable to determine the place of delivery of goods through an INCOTERM under Article 7(1)(b) of the Brussels I Recast Regulation.

51. This author disagrees with CASTELLANOS RUIZ in criticising the Electrosteel case where the CJEU prevents the national judge from applying the substantive law in order to determine the place of delivery of the goods under the so-called 'Car Trim formula'. The reasoning is the following: Certain authors such as SALERNO ${ }^{107}$ follow the "thesis of the relevance of the CISG as a legal instrument to provide for jurisdiction in the context of Article 7(1) of the Brussels I Recast Regulation". They defend the criteria set out by Article 31(a) of the CISG under which the relevant place for the delivery of the goods is where the first carrier takes possession of the goods and not the place of delivery according to Article 7(1)(b) of the Brussels I Recast Regulation.

52. However, the predominant theory, followed by the CJEU, contradicts the previous one since it would favour the seller to the detriment of the buyer. According to Di BLASE, the most relevant element is the place of delivery determined by the contract and not the one provided by CISG even if the Convention constitutes the substantive law applicable to the contract. ${ }^{108}$ The Brussels I Recast Regulation does not explicitly mention the CISG in its Article 7. The CJEU has ignored any reference to CISG when determining the place of delivery. ${ }^{109}$ The CJEU has accepted, nevertheless, the "theory of the hermeneutic value" of the CISG in order to interpret substantive legal concepts contained in the Brussels I Recast Regulation such as "purchase and sale of goods" or "provision of services" but not concepts such as place of delivery to determine the international jurisdiction. ${ }^{110}$

53. It is widely understood that the most efficient solution in order to determine jurisdiction relies on party autonomy. The parties have the power to determine the court where they will solve any dispute arising out of the contract according to Articles 25 and 26 of the Brussels I Recast Regulation. ${ }^{111}$ This is the most efficient solution since the parties are better informed about their contractual relationship than the judge.

${ }^{107}$ F. SALERNO, "Le conseguenze della proposta di regolamento "Roma I" sulla legge italiana di diritto internazionale privato", in G. Carella (ed.), Il nuovo diritto europeo dei contratti, dalla Convenzione di Roma al regolamento "Roma I", Milan, 2007, pp. 179-195; in A.-L. Calvo Caravaca and J. Carrascosa González (note 37), p. 850.

108 A. Di Blase, "La giurisdizione competente in materia di compravendita e di prestazione di servizi nel Regolamento Bruxelles I", Europa e Diritto Privato, no. 2, 2011, pp. 459-479; in A.-L. Calvo CaravaCa and J. Carrascosa GonzÁlez (note 37), p. 850.

${ }^{109}$ Car Trim judgment, paragraphs 58-60.

${ }^{110}$ Ibid., paragraphs 34-39; in A.-L. Calvo Caravaca and J. Carrascosa GonzÁlez (note 37), pp. 850-851.

111 Vid. E. Castellanos Ruiz (note 93), at p. 118. 


\section{Non-contractual actions under Article 7(2) of the Brussels I Recast Regulation}

54. The criteria set out by the CJEU regarding the place of performance in contracts for delivery of goods or the provision of services are not applicable when the claimant starts proceedings in tort, delict o quasi-delict of Article 7(2) and party autonomy will be diminished. Neither a binding jurisdiction agreement fulfilling the criteria set out by Articles 25 and 26 of the Brussels I Recast Regulation, nor a valid arbitral agreement complying with the national legislation in force (in most of the countries, the New York Convention) ${ }^{112}$ will be enforceable in an EU Member State court in such case.

55. A distinction must be drawn between the different proceedings where special jurisdiction may be an issue that can be brought under the Brussels I Recast Regulation: on one hand, the previously analysed actions concerning the "validity or invalidity of the contract" of Article 7(1); on the other hand, the "proceedings which seek compensation or other payment because of fault in negotiating or in failing to negotiate a contract, or a response to a wrong which induced another to enter into a contract (culpa in contrahendo)" of Article 7(2). ${ }^{113}$ Preventive actions are also included within the meaning of Article 7(2) of the Brussels I Recast Regulation, ${ }^{114}$ Their territorial scope of application in jurisdictions like Spain remains unclear. ${ }^{115}$

56. How is the court having jurisdiction determined in case of multiple places where a harmful event occurs? The CJEU has harmonised the accumulation of actions in tort based on actions pending in EU Member State courts according to Article 7(2) of the Brussels I Recast Regulation. ${ }^{116}$ There is a lack of harmonisation between the civil law of EU Member States and the lex causae of each characterises the type of claim arising out of every tortious claim. ${ }^{117}$

57. The Brogsitter case ${ }^{118}$ reinforced the CJEU's criteria related to actions in tort under national law. These actions should be distinguished from "matters relating to a contract" within the scope of Article 7(1)(a) of the Brussels I Recast Regulation. The CJEU held in the Granarolo case that the claimant cannot choose exercising a claim under Articles 7(1) and 7(2) since "the court determines the jurisdictional category into which the claim falls" being "based on autonomous definitions" for the purposes of the Brussels I Recast Regulation. ${ }^{119}$ The conduct of the defendant will be considered as a breach of contract

112 Convention on the Recognition and Enforcement of Foreign Arbitral Awards (1958 New York Convention) (adopted 10 June 1958, entered into force 7 June 1959) 330 UNTS 38.

113 A. BRIGGS (note 7), at [2.170].

114 Judgment of 1 October 2002, Verein für Konsumenteninformation v Karl-Heinz Henkel, C-167/00, EU:C:2002:555; Vid. See D. C. JACKSON, Enforcement of Maritime Claims, Informa Law from Routledge, 2013, at [6.158].

${ }^{115}$ For instance, in Spain, a broad interpretation shall be given to Article 22 quinquies b) of the Spanish Organic Law 6/1985 of 1 July on the Judiciary ('Ley Orgánica 6/1985, de 1 de julio, del Poder Judicial in Spanish) published in the Spanish Official State Gazette, No. 157 of 2 July 1985 and amended by the Organic Law 7/2015 of 21 July 2015, in order to include preventive actions. The rule contains a similar forum to that of Article 7(2) of the Brussels I Recast Regulation but makes the Spanish courts competent when "the harmful event occurred in Spanish territory" instead of "the place where the harmful event occurred or may occur"; L. CARBAllo PIÑEIRO, Collective actions and their extraterritorial effectiveness: problems of reception and transplantation of class actions in Europe, Publications Service of the University of Santiago de Compostela, 2009, p. 123; M. A. CeBrí́n SALVAT (note 48), at p. 148.

${ }^{116}$ According to the Article, a person domiciled in an EU Member State may be sued in another EU Member State "in matters relating to tort, delict or quasi-delict, in the courts for the place where the harmful event occurred or may occur."

117 S. SÁnchez Lorenzo, "Delimitation entre matiere contractuelle et matiere delictuelle dans l'Espace judiciaire europeen (l'affaire Brogsitter)", Annuarie de Droit de l'Union Europénne, vol. 38, 2014, pp. 472-478, in Á. Espiniella Menendez, "International Jurisdiction in Respect of Unfair Acts with Competitors", Cuadernos Derecho Transnacional vol. 10, 2018, no. 2, pp. 276-305.

118 "Only when a contract does not fall within either of those two categories [...] it is appropriate to determine the competent jurisdiction in accordance with the connecting factor provided for" in Article 7(1)(a) of the Brussels I Recast Regulation (Brogsitter case at paragraph 28); see the Decree of the court of Varese of 27 October 2012, no. 27 (judge GiUSEPPE BUFFONE) where Articles 5(1)(a) and 5(1)(b) of the Lugano Convention was not applicable in the sale of goods and provision of services by an Italian seller of goods and provider of services to a Swiss buyer and receiver of the services; A.-L. CALVo CARAVACA and J. CARrascosa GonZÁlez (note 37).

119 A. Briggs (note 7), at [2.171] and [2.192]. 
by an EU Member State court taking into account the purpose of the contract in order to determine the lawful or unlawful nature of the claim. ${ }^{120}$ However, the doctrine partially disagrees with the extensive interpretation of contractual matters. ${ }^{121}$ The reasons are the possibility of a court setting jurisdiction as a contractual matter and in tort in relation to the applicable law. The danger is that the CJEU applies the same interpretation to contractual matters of Article 7(1) of the Brussels I Recast Regulation, aimed to provide for special jurisdiction, and the Rome I Regulation, while the functions entrusted to these rules are different. ${ }^{122}$ Moreover, the defendant may avoid being judged in tort by virtue of the autonomous characterisation given to the contractual relation. ${ }^{123}$ The non-compliance with an unequivocally accepted and unfulfilled tacit contract may lead to contractual liability. ${ }^{124}$

58. The facts of the case and not the national applicable law characterise the existence of a "long-standing business relationship" 125 that must "not be presumed and must [...] be demonstrated". There must be "a body of consistent evidence, which may include in particular the existence of a longstanding business relationship, the good faith between the parties, the regularity of the transactions and their development over time expressed in terms of quantity and value, any agreements as to prices charged and/or discounts granted, and the correspondence exchanged". ${ }^{126}$ The national judge will identify the unfulfilled obligation leading to a breach of contract. If the contractual relationship between Granarolo and Ambrosi for breach of contract without notice had not been characterised as a long-term relationship, the French judge would not have determined the applicable law under French national law but under the Brussels I Regulation. ${ }^{127}$

59. The CJEU conferred jurisdiction to the courts of the place where the act causing damage or where the damage occurred in the Mines de Potasse d'Alsace case. ${ }^{128}$ However, the court in the Shevill judgment ${ }^{129}$ specified further criteria concerning the allocation of jurisdiction. Each EU Member State has jurisdiction for the damage cause within its jurisdiction but the EU Member State where the harmful event occurred has jurisdiction in relation to the whole damage originated in that State. The place of origin usually coincides with the place of domicile of the defendant and the criterion does not provide an additional forum to Article 4 of the Brussels I Recast Regulation. ${ }^{130}$ The Barclays Bank case ${ }^{131}$ reinforces the CJEU's case law ${ }^{132}$ in its paragraph 27, describing the place where the harmful event occurs as "the place is that where the alleged damage actually manifests itself." 133

120 G. VAN CALSTER (note 23), pp. 144-163.

121 See P. Mankowski, “Article 7”, in U. Magnus and P. Mankowski European Commentaries on Private International Law. Brussels I bis Regulation, Otto Schmidt, 2016, pp. 168-169; P. HubER, "Auf ein Neues: Vertrag und Delikt im europäischen I(Z)PR (zu EuGH 14.7.2016- Rs. C-196/15-Granarolo SpA / Ambrosi Emmi France SA, unten S. 396, Nr. 22)", IPRax: Praxis des Internationalen Privat-und Verfahrensrechts, vol. 37, 2017, no. 4, pp. 358-360, in I. ANTÓN JuÁREZ (note 43), pp. $528-529$.

122 P. MankowsKi (note 121), pp. 166-168; I. ANTÓN JuÁrez (note 43), pp. 528-529.

123 P. MANKowsKi (note 121), p. 168; I. ANTÓn JuÁREZ (note 43), pp. 528-529.

124 Granarolo case, paragraph 24.

125 Ibid., paragraph 25.

126 Ibid.,paragraph 26.

127 I. ANTÓN JuÁREZ (note 43), pp. 528-529.

128 Judgment of 30 November 1976, Handelskwekerij G. J. Bier BVv Mines de potasse d'Alsace SA, C-21/76, EU:C:1976:166.

129 Judgment of 7 March 1995, Fiona Shevill, Ixora Trading Inc., Chequepoint SARL and Chequepoint International Ltd $v$ Presse Alliance SA, C-68/93, EU:C:1995:61.

130 P. De Miguel Asensio, Derecho Privado de Internet, Cizur Menor, Thomson Reuters Civitas, 2015, p. 199; in Á. EspinIELLA MENENDEZ (note 117), pp. 276-305.

131 Judgment of 12 September 2018, Helga Löber v Barclays Bank PLC, C-304/17, EU:C:2018:701.

132 Judgment of 21 May 2015, CDC Hydrogen Peroxide, C352/13, EU:C:2015:335, paragraph 52.

133 The eDate Advertising case, only applicable to the infringement of personality rights on internet expanded the Shevill criteria by allowing the claimant to choose between the place where the harmful event occurred and the domicile of the defendant. The interpretation of the CJEU led to the jurisprudential creation of a new forum actionis. The court where the claimant resides has jurisdiction "on all the damage caused globally by the tort" in cases of defamation on internet. The court has jurisdiction for the damages caused in other countries; Vid. P. Beaumont, M. Danov, K. Trimmings, and B. Yüksel (eds.), Cross-Border Litigation in Europe, Bloomsbury Publishing, 2017, at p. 525. 
60. For matters related to damages originated from a ship in the High Seas, the CJEU has "equated the damage created by industrial action occurring on a ship" with the country of registration of the ship in order to identify the place where the harmful event took place. ${ }^{134}$ The CJEU has dismissed any assessment of the relationship between the ship and the registration of the vessel without taking into consideration the role of flags of convenience. ${ }^{135}$

61. The criteria followed by the court's case law related to the place of delivery of the goods carried by sea from Melbourne to Rotterdam in order to reach France by land was considered to be the port of delivery in the Réunion européenne judgment, ${ }^{136}$ i.e. the claimant's domicile. The French consignees of the shipped pears sued the Australian issuers of the bill of lading in contract and the Dutch carriers and the master of the ship in tort but the court held that the these claims "cannot be regarded as connected". ${ }^{137}$ None of the defendants were domiciled in France and the French courts were not found competent to hear the case. The CJEU referred to the previous Kalfelis case ${ }^{138}$ under which "a court which has jurisdiction under the current Article 7(2) of the Brussels I Recast Regulation over an action in so far as it is based on tort or delict does not have jurisdiction over that action in so far as it is not so based". ${ }^{139}$

\section{The applicable law to contracts for the provision of services, the sale of goods and complex contracts under European Union Law}

\section{The applicable law to contractual claims}

62. In order to address which legal framework will apply the judge to a contractual claim the already mentioned Article 4 of the Rome I Regulation shall be analysed. As already stated in previous sections the CISG takes precedence over the Rome I Regulation in order to determine the certain "substantive applicable rules" to contracts for the international sale of goods. It shall be born in mind the territorial scope of application of that instrument that is in force in most of the EU Member States excluding the UK and Portugal. However, focus will be put in this section in the choice of law for other types of contracts rather than the sale of goods. The single service contract including carriage of goods by sea, air or road fall under the scope of application of the Rome I Regulation.

63. The freedom of choice of law by the parties is enshrined in Article 3 of the Rome I Regulation and if the parties have not agreed it Article 4 is applicable. Article 4(1) presents direct, rigid and not presumptive connecting factors in order to determine the applicable law to a contract. These diverge from other type of connecting factors that do not necessarily relate to the principle of proximity and the closest connection of the contract to a specific country. ${ }^{140}$ The characteristic performance is the connecting factor to consider in Article 4(1) of the Rome I Regulation. In contrast, Article 4(1) of the Rome Convention allowed evaluating the main elements of the contact in order to escape from the "inefficient tyranny of the characteristic performance". ${ }^{141}$ The global cost of the eight contracts included in Article 4 paragraphs (1) and (2) are economically inefficient for the contractual parties. ${ }^{142}$

\footnotetext{
134 Judgment of 5 February 2004, Danmarks Rederiforening, acting on behalf of DFDS Torline A/S v LO Landsorganisationen $i$ Sverige, acting on behalf of SEKO Sjöfolk Facket för Service och Kommunikation, C-18/02, EU:C:2004:74, at paragraph 44.

135 Vid. D. C. JACKSON (note 114) at [6.165].

136 Judgment of 27 October 1998, Réunion européenne SA and Others v Spliethoff's Bevrachtingskantoor BV and the Master of the vessel Alblasgracht V002, C-51/97, EU:C:1998:509.

${ }^{137}$ Ibid., at paragraph 50.

138 Judgment of 27 September 1988, Athanasios Kalfelis v Bankhaus Schröder, Münchmeyer, Hengst and Co. and others, C-189/87, EU:C:1988:459.

139 Paragraph 49 of the Réunion européenne case; Vid. D. C. JACKSON (note 114) at [6.166].

${ }^{140} \mathrm{~S}$. FRANCQ, "Le règlement «Rome I» sur la loi applicable aux obligations contractuelles. De quelques changements...", Journal du droit international (Clunet), vol. 136, 2009, no. 1, pp. 41-69.

${ }^{141}$ L. F. CARrillo Pozo "La ley aplicable al contrato en defecto de elección: un análisis de la jurisprudencia", Revista del poder judicial, no. 74, 2004, pp. 11-46.

${ }^{142}$ S. FrancQ (note 140), pp. 41-69.
} 
64. According to Article 4(1) of the Rome I Regulation, in the absence of choice, pursuant to Recital 19, the applicable law should be determined in accordance with the choice of law rule specified for the particular type of contract. Article 4(1) of the Rome I Regulation provides the specific choice of law rule for each particular type of contract: ${ }^{143}$

"(a) a contract for the sale of goods shall be governed by the law of the country where the seller has his habitual residence;

(b) a contract for the provision of services shall be governed by the law of the country where the service provider has his habitual residence";

65. The applicable law is that of the habitual residence of the service provider. This is the place where it has its central administration, principal place of business, or if under its terms the contract is the responsibility of a branch, agency, and so on, the place where that branch is located according to Article 19 (habitual residence) of the Rome I Regulation.

66. However, Article 4(1) of the Rome I Regulation favours one of the parties in contracts for the sale of goods (subparagraph a), contracts for the provision of services (subparagraph b), as well as in relation to franchise (subparagraph e) and distribution (subparagraph f) contracts. ${ }^{144}$ Such imbalance is higher or lower for each contractual party respectively. The remaining contracts envisaged by Article 4(1) of the Rome I Regulation designate the most foreseeable laws by the parties that create the lowest global costs for each, i.e. the law of the country most closely linked to the contract, the Law of the country where the "centre of gravity of the contract" is located, ${ }^{145}$ or the Law of the country of the "seat of the legal relationship". ${ }^{146}$

67. The mixed or complex contracts of Article 4(2) of the Rome I Regulation involve several types of contracts formed by varied contractual elements that differ, having a different material or substantial regulation in most of the domestic laws of each EU Member State. The key element to classify a contract as mixed or complex under the Rome I Regulation is the economic purpose of the contract and mixed or complex contracts provide for more than one. Under Article 4(2) Rome I Regulation, the law that governs a mixed or complex contract is the one of where the party required to effect the characteristic performance of the contract has its habitual residence. ${ }^{147}$ Since, in most cases, this will also be the country where the buyer is habitually resident, it is highly unlikely that the court will seek to escape from that result by reference to Article 4(3): ${ }^{148}$

"[...] where it is clear from all the circumstances of the case that the contract is manifestly more closely connected with a country other than that indicated in paragraphs 1 or 2 , the law of that other country shall apply."

68. The designated law under Article 4(2) of the Rome I Regulation is applicable when the contract presents different elements from various contracts related to Article 4(1) of the Rome I Regulation. Then, the law applicable to those contracts will be determined according to Article 4(2) of the Rome I Regulation, as this Article and Recital 19 of the Rome I Regulation expressly indicate: ${ }^{149}$

${ }^{143}$ If one does not fall within Article 4(1), the basic choice of law rule is contained in Article 4(2).

144 M.-E. ANCEL, "Les contrats de distribution et la nouvelle donne du réglement Rome I," Revue critique de droit international privé, vol. 97, 2008, no. 3, pp. 561-579; P. PIRODDI, "Incoterms e luogo di consegna dei beni nel regolamento Bruxelles I", Rivista di diritto internazionale privato e processuale, vol. 47, 2011, no. 4, pp. 939-970.

${ }_{145}$ E. VitTa, "Influenze americane nella convenzione C.E.E. sulle obbligazioni contrattuali”, Riv. Dir. int. priv. proc., vol. 19, 1983, no. 2, pp. 261-278, at pp. 264-265; O. vON Gierke, Deutsches Privatrecht, 1895, vol. 1, p. 217.

146 A.-L. Calvo Caravaca and J. Carrascosa González (note 37), pp. 934-937.

${ }^{147}$ Ibid., p. 986.

${ }^{148}$ N. ENONCHONG (note 12), pp. 194-215, at p. 203.

149 Ibid., p. 194-215, at p. 201. 
"Where there has been no choice of law, the applicable law should be determined in accordance with the rule specified for the particular type of contract. Where the contract cannot be categorised as being one of the specified types or where its elements fall within more than one of the specified types, it should be governed by the law of the country where the party required to effect the characteristic performance of the contract has his habitual residence. In the case of a contract consisting of a bundle of rights and obligations capable of being categorised as falling within more than one of the specified types of contract, the characteristic performance of the contract should be determined having regard to its centre of gravity."

69. Therefore, only one legal regime will be applicable to the entire mixed or complex contract: The law of the habitual residence of the party required to effect the characteristic performance of the contract as a consequence of applying Article 4(2) of the Rome I Regulation. ${ }^{150}$ According to LANDO and NiELSEN, ${ }^{151}$ Article 4(2) of the Rome I Regulation states that contracts not listed in Article 4(1) or contracts covered by more than one of points (a) to (h) are governed by the law of the country in which the party that is required to effect the characteristic performance of the contract has its habitual residence. If the law applicable cannot be determined pursuant to Articles 4(1) or 4(2), the contract shall be governed by the law of the country with which it is most closely connected according to Article 4(4) of the Rome I Regulation: "Where the law applicable cannot be determined pursuant to paragraphs 1 or 2 , the contract shall be governed by the law of the country with which it is most closely connected".

70. Unlike Article 4(2), Article 4(3) of the Rome I Regulation does not contain any guidelines on how to exercise this discretion. However, a guideline is provided by the second sentence of Recital 20 of the Rome I Regulation, stating that "in order to determine whether the contract is manifestly more closely connected to another country, account should be taken, inter alia, of whether the contract in question has a very close relationship with another contract or contracts". ${ }^{152}$

71. A contract for the provision of services might be crystal clear under Article 4(1)(b). The relevant element to consider is the purpose of the contract (the sale of goods or provision of services). Most of the mixed or complex contracts include different types of contracts of the referred Article, falling within the scope of Article 4(2). However, the problem arises if the seller is providing a full range of services to the buyer while assuming different functions. These may include the sale of goods but the provision of services, including the carriage of goods, is the main economic purpose and do not fall within Article 4(2). They normally involve a range of different contracts falling within the scope of Article 4(1)(b) of the Rome I Regulation, under which a contract for the provision of services shall be governed by the law of the country where the service provider has its habitual residence. The contract for the provision of services including the carriage of goods by sea or other means of transport constitutes a contract for the provision of services for the Rome I Regulation. However, the characterisation of such contract depends on the applicable national law ex Rome I Regulation. For instance, it constitutes a mixed or complex contract under Spanish law or other national laws, e.g. in case of a Turn-key contract or key in hand contract. ${ }^{153}$ Nevertheless, there is neither a definition of "provision of services" in the Rome I Regulation nor a decision by the CJEU providing one.

\section{The applicable law to non-contractual claims}

72. Non-contractual obligations have a different treatment and do not provide for the application of international conventions such as CISG that relates to the applicable law to contract matters. The Rome II Regulation applies to the choice of law before the courts of an EU member State in case of

\footnotetext{
150 A.-L. Calvo Caravaca and J. Carrascosa González (note 37), p. 986.

151 O. Lando and P. A. Nielsen, “The Rome I Regulation”, Common Market Law Review, vol. 6, 2008, no. 45, pp. 16871725.

${ }^{152}$ Ibid., pp. 1687-1725.

153 A.-L. Calvo Caravaca and J. Carrascosa González, "Articles 1 \& 2", in U. Magnus and P. Mankowski (eds.), Rome I Regulation - Commentary, European Commentaries on Private International Law (ECPIL), Otto Schmidt, 2017, pp. 52-87.
} 
"non-contractual obligations arising out of strict liability", an "autonomous concept" that "varies from one Member State to another" according to Recital 11.

73. The concept focuses on actions in tort including unjust enrichment (Article 10), negotiorum gestio (Article 11) and culpa in contrahendo (Article 12). The Rome II Regulation may lead to the application of the law of a non-EU Member State. It is not applicable to a maritime tort arising out of a damage occurred in the High Seas but it is applicable to one occurred in the territorial waters of an EU Member State. Article 4(1) introduces the general rule of Rome II Regulation under which "the law applicable to a non-contractual obligation arising out of a tort/delict shall be the law of the country in which the damage occurs," unless "the person claimed to be liable and the person sustaining damage both have their habitual residence in the same country at the time when the damage occurs, the law of that country shall apply" according to Article 4(2) of the Regulation. An exception to the general rule is provided by Article 4(3). A tort or delict "manifestly more closely connected" to any country other than that provided by the first two paragraphs of Article 4 leads to the application of the law of that other country.

74. Article 4(3) of the Rome II Regulation mimics Article 4(3) of the Rome I Regulation making applicable the law of the country more closely connected to the contract. Article 14(1) (freedom of choice) of the Rome II Regulation provides for the choice of law by the parties in case of "an agreement entered into after the event giving rise to the damage occurred" or "where all the parties are pursuing a commercial activity, also by an agreement freely negotiated before the event giving rise to the damage occurred". Third party rights are protected and the choice of law must be "expressed or demonstrated with reasonable certainty". However, if all the elements are connected to the country where the damage occurred the public policy exception of that country will be applicable even if the parties have chosen another country's law under Article 14(2) of the Rome II Regulation.

75. Article 16 sets out that overriding mandatory provisions of the law of the forum are "mandatory irrespective of the law otherwise applicable to the non-contractual obligation". EU law provisions are applicable "where appropriate as implemented" in the EU Member State of the forum "where all the elements relevant to the situation at the time when the event giving rise to the damage occurs are located in one or more" EU Member States according to Article 14(3) of the Rome II Regulation.

\section{Cheapest cost avoider, efficiency in the conflict of laws and game theory}

76. The contracts for the sales of goods and provision of services including the single service contract serve as a guiding thread during the following analysis based on the varied theories that consider the cost and efficiency in case of conflict between two parties. What is the cost for the parties in dispute according to legal and economic theories? First, the neo-classical theory is explained followed by the "International Stream-Of-Commerce". Second, concrete examples are provided through the prisoner's dilemma regarding the applicable law.

77. The predominant neo-classical legal and economic theory is "based on the belief in markets and cherishing efficiency". The most efficient law is the one used by most of the participants engaged in commercial transactions. ${ }^{154}$ Party autonomy tends to reduce the transaction costs. ${ }^{155}$ It comes "as close as

${ }_{154}$ M. KLAUSNER, "Corporations, corporate law, and networks of contracts." Virginia Law Review, vol. 81, 1995, no. 3, pp. 757-852, at p. 785; S. VogEnAuER, "Regulatory competition through choice of contract law and choice of forum in Europe: theory and evidence", in Horst Eidenmüller (ed.), Regulatory Competition in Contract Law and Dispute Resolution, Verlag C.H. Beck and Hart Publishing, 2013, pp. 227-286, at p. 235); G. RüHL, "Wettbewerb der Rechtsordnungen im Vertragsrecht Wunsch oder Wirklichkeit?”, in U. Ehricke, W. KAAL, M. SCHMIDT and A. SchwartZe (eds.), Festschrift für Christian Kirchner, Mohr Siebeck, 2014, pp. 975-994, at p. 978.

${ }^{155}$ D. Bureau and H. Muir Watt Droit international privé, $2^{\text {nd }}$ ed., Puf, vol. 1, 2010, p. 532; M.-P. Weller, "Anknüpfungsprinzipien im Europäischen Kollisionsrecht: Abschied von der" klassischen, IPR-Dogmatik?",IPRax: Praxis des Internationalen Privat-und Verfahrensrechts, vol. 31, 2011, no. 5, pp. 429-437, at p. 433. 
possible to the parties' ex ante will", it does not "overtax informational capacities" and "provides courts with simple rules which in most cases lead to syllogistic decisions". ${ }^{156}$

78. The "International Stream-Of-Commerce" theory is based on the assumption that the party that can afford applying a foreign law is the one that has provided the internationality element to the contract, ${ }^{157}$ while placing such foreign country and its law in its legal sphere. ${ }^{158}$ The judge acknowledges the substantive private law nature of the risk born by one of the parties when applying the designated law by the conflict rule. ${ }^{159}$ There are two modes of internationalising a contract, through commercials targeting a foreign market or through an offer addressed to that foreign market. An efficient conflict rule should not declare applicable the law or the seller or the buyer to an international contract but should be ascertained by the judge from the "territorial links of the case to the different States" according to the contract. ${ }^{160}$

79. The global cost of applying the law of the country where the seller has its habitual residence according to Article 4(1)(a) of the Rome I Regulation is not the most efficient in comparison to the law of the country of the habitual residence of the buyer/services purchaser, the law of the country where the offer is addressed or the law of the country where the goods are delivered or the services are provided. ${ }^{161}$

80. The law of the country where the contract is performed ("Lex Loci Executionis"), the "natural seat of contractual obligations", is the most efficient and preferred one by the parties to an international contract. ${ }^{162}$ Article 12(2) of the Rome I Regulation points out that "in relation to the manner of performance and the steps to be taken in the event of defective performance, regard shall be had to the law of the country in which performance takes place". This criterion is more efficient than the place of habitual residence of the characteristic performer ${ }^{163}$ and is the one followed in order to provide for jurisdiction according to Article 7(1) of the Brussels I Recast Regulation. ${ }^{164}$

81. This theory crumbles when there are multiple places of performance, the place of performance is located in a third country where the contractual parties do not reside (e.g. the place of delivery of the goods or payment of the price), ${ }^{165}$ the place of performance is not specified in the contract and the applicable law must be determined beforehand (circular problem) ${ }^{166}$ and when optional places of performance are set up by the parties ${ }^{167}$ or these include optional positive or negative obligations to perform in different countries. ${ }^{168}$

${ }^{156}$ H.-B. SchäFER and K. Lantermann, "Choice of law from an economic perspective", in J. Basedow and T. Kono (eds.), An economic analysis of private international law, Mohr Siebeck, 2006, pp. 87-120, at p. 188; in P. MANKowsKI, “Article 3", U. Magnus and P. ManKowsKi (note 153), pp. 120-121.

157 J. CARrascosa GonzÁlEz, "Contratos internacionales, prestación característica y la teoría de la Stream of Commerce", in A.-L. Calvo Caravaca and P. Blanco-Morales Limones (eds.), Globalizaciòn y Derecho, 2003, pp. 87-119; F. J. Garcimartín AlfÉrez, "La racionalidad económica del DIPr", Cursos de Derecho Internacional de Vitoria-Gasteiz 2001, 2002, pp. 88-154.

${ }^{158}$ F. J. Garcimartín Alférez, Derecho de sociedades y conflictos de leyes: una aproximación contractual, Editoriales de Derecho Reunidas, 2002, p. 224.

159 J. C. Paz-Ares Rodríguez, "Principio de eficiencia y Derecho privado", in Estudios de Derecho mercantil en homenaje al profesor Manuel Broseta Pont, Tirant lo Blanch, 1995, pp. 2,843-2,900, at pp. 2,845-2,846.

160 J. Carrascosa GonzÁlez, Conflicto de leyes y teoría económica, Colex, 2011, pp. 226-229.

${ }^{161}$ Ibid., pp. 230.

${ }^{162}$ F. K. von SAVIGnY, Sistema del derechoromano actual, translated to French by M. C. Guenoux and translated to Spanish by J. Mesía and M. Poley, Centro Editorial Góngora, 1879, vol. VIII, Comares, 2005, pp. 1417 and 1419.

163 V. Heuzé AND P. MAYer (note 91), p. 534.

${ }^{164}$ L. F. CARRILlo Pozo, "Rigor mortis. La Ley aplicable al contrato a falta de elección en los trabajos de reforma del Convenio de Roma de 1980", in Hacia un derecho conflictual europeo: realizaciones y perspectivas: Verso un diritto internazionale privato europeo: risultati e prospettive, University of Sevilla, 2008, pp. 11-41; Ibid. (note 141), pp. 11-46.

${ }^{165}$ D. Holleaux, J. Foyer, G. de Geouffre de La Pradelle, Droit International Privé, Masson, 1987, pp. 592-600.

166 M. Virgós SoriAno, "La ley aplicable a los contratos internacionales: la regla de los vínculos más estrechos y la presunción basada en la prestación característica del contrato", in Estudios jurídicos en homenaje al profesor Aurelio Menéndez, vol. IV, Civitas, 1996, pp. 5,289-5,409, at p. 5,302.

${ }^{167}$ D. McClean and K. Beevers, Morris, The Conflict of Laws, $6^{\text {th }}$ ed., Thomson, Sweet \& Maxwell, London, 2005, p. 254.

168 J. CARRascosa GonzÁlez (note 160), pp. 232-234. 
82. The theory of characteristic performance of the Rome I Regulation is inefficient compared to the thesis of the "International Stream-Of-Commerce" and the thesis of the place of performance of the contract. It is desirable to have the same conflict rule applicable to each type of international contract in order to achieve an efficient conflict of laws solution. ${ }^{169}$ The conflictual efficiency must be calculated in a holistic way taking into account: first, the national law that distributes the global costs of conflict in a balanced way, and second, the law that implies lower overall cost for the parties to an international contract. It makes limited sense that the "place of performance" serves as the basis to determine the "international jurisdiction and that it would be irrelevant for the determination of the applicable law". ${ }^{170}$

83. The inefficiency of the characteristic place of performance is explained below relying on game theory. A parallelism is provided to explain the theory of cost of conflict applied to the sale of goods and provision of services through the well-known prisoner's dilemma: ${ }^{171}$

\begin{tabular}{|c|c|c|}
\hline & $\begin{array}{c}\text { Keeps quiet } \\
= \\
\text { Cooperates }\end{array}$ & $\begin{array}{c}\text { Confesses } \\
= \\
\text { Defects }\end{array}$ \\
\hline $\begin{array}{c}\text { Keeps quiet } \\
= \\
\text { Cooperates }\end{array}$ & $-1 / 2,-1 / 2$ & $-4,0$ \\
\hline $\begin{array}{c}\text { Confesses } \\
= \\
\text { Defects }\end{array}$ & $0,-4$ & $-2,-2$ \\
\hline
\end{tabular}

84. If a prisoner confesses and testifies against the other prisoner (i.e. the judge will decide over its international jurisdiction based on the Brussels I Recast Regulation and the applicable law based on the connecting factor according to the Rome I Regulation), he will go free, while the other will receive the maximum sentence of four years (the seller/service provider or the buyer/services will assume an unbalanced global cost of conflict). ${ }^{172}$ If both prisoners confess (i.e. the global costs of the operation are shared implying a lower overall transactional cost for the parties), they will each get two years in prison for burglary. If neither confesses, each prisoner will get half a year in prison for possession of stolen goods (i.e. the judge will not assume jurisdiction to hear the case since the parties have agreed the jurisdiction and applicable law to the international contract). ${ }^{173}$

85. Confession is the dominant strategy ${ }^{174}$ since the parties cannot cooperate and reach a binding agreement. ${ }^{175}$ The inefficient Nash Equilibrium ${ }^{176}$ of the prisoner's dilemma requires a joint optimisation

169 B. Audit, "Le caractère fonctionnel de la règle de conflit (Sur la "crise" des conflits de lois)", Recueil des cours de Droit International, vol. 186, 1984, pp. 219-398, at pp. 294-297.

${ }^{170}$ V. Heuzé and P. Mayer (note 91), p. 534; L. F. Carrillo Pozo (note 164), pp. 11-41); in J. Carrascosa González (note 160), p. 238.

${ }^{171}$ Two individuals are arrested in possession of stolen goods, imprisoned and separated from each other. They do not trust each other and decide not to cooperate since the penalty (i.e. the cost of conflict for each party to an international contract) is lower in case of possession of stolen goods than burglary. The prosecutor needs a confession of one of both prisoners to sentence them for burglary instead of possession of stolen goods. He offers an individual deal to each prisoner; A. RAPOPORT and A. M. Снамман, Prisoner's Dilemma: A Study in Conflict and Cooperation, Univ. of Michigan Press, 1965, at pp. 24-25; in C. E. Bagley and C. D. Tvarnø, "Pharmaceutical public-private partnerships in the United States and Europe: Moving from the bench to the bedside", Harv. Bus. L. Rev. 4, 2014, pp. 373-401, at p. 387.

172 C. D. Tvarnø, "Partnering Contracts: A Solution to the Nash Equilibrium? In a Contract Law and Game Theory Perspective", Behavioral Analysis Applied to Economics and to Law, 2013, pp. 1-13.

${ }^{173}$ A. Rapoport and A. M. Chammah (note 171), pp. 373-401; D. Kreps, P. Milgrom, J. Roberts and R. Wilson, "Rational cooperation in the finitely repeated prisoners' dilemma", Journal of Economic theory, vol. 27, 1982, no. 2, pp. 245-252. pp. 245-252; E. Rasmusen, Games and Information: An Introduction to Game Theory, Basil Blackwell, 1989.

174 I. Ayres, "Playing games with the law",Stan. L. Rev., vol. 42, 1990, no. 5, pp. 1291-1317.

175 C. E. Bagley and C. D. Tvarnø (note 171), pp. 373-401.

176 S. J. Grossman and O. D. Hart, "The costs and benefits of ownership: A theory of vertical and lateral integration", The Journal of Political Economy, vol. 94, 1986, pp. 691-719. 
from a game theory perspective. The "Pareto optimal" is reached "if the contract is impossible to modify (within the type of contract) so as to raise the expected utility of both of the parties to it; such a contract will sometimes be referred to as simple and efficient or as mutually beneficial". ${ }^{177}$ From a new institutional and economics perspective based on the role of institutions and potential incentives for legal players, the prisoners will act will employing mental shortcuts not following mathematic rules since they lack of vital information. ${ }^{178}$ However, it could be said that the prisoners' choice of law is Kaldor/Hicks efficient if it has no negative impact on the State or third parties' interests. ${ }^{179}$

86. The application of the law of a third State to an international contract halts international trade..$^{180}$ CARRASCOSA GonZÁLEZ advises applying Article 4(3) of the Rome I Regulation instead of the law of the place of residence of the seller of Article 4(1) of the Rome I Regulation. Article 4(3) of the Rome I Regulation prescribes that "where it is clear from all the circumstances of the case that the contract is manifestly more closely connected with a country other than that indicated in paragraphs 1 or 2, the law of that other country shall apply". The Article leads to the application of the law of the goods or services purchaser, i.e. the law of the country of performance of the contract and the country where the offer is addressed. ${ }^{181}$

87. Contracts for the provision of services seem to be more efficient when the connecting factor is based on the "International Stream-Of-Commerce" theory relying on the habitual residence of the service customer (i.e. where the service has been offered). The habitual residence of the service provider is a more inefficient criterion. The global cost of conflict for each party may be more efficient applying the "International Stream-Of-Commerce" theory rather than the place of performance theory. It may also provide for a lower overall cost. However, the law of the place of performance may be lower depending on the circumstances of both parties if the cost of applying a foreign law comprises a lower global and overall cost of conflict for each. ${ }^{182}$

88. The law chosen by the parties, in case of a non-contractual action under Article 14 of the Rome II Regulation, provides for the most efficient substantive law that the parties previously knew (or benefits them the most $)^{183}$ while providing them the lowest cost of conflict. ${ }^{184}$ The lex domicilii communis partium, i.e. the law of the place where "the person claimed to be liable and the person sustaining damage both have their habitual residence in the same country at the time when the damage occurs", ${ }^{185}$ provides for a lower cost of conflict in contrast to the law of the country where the damage occurs (lex damni), which cannot be understood as the one of the place where the fact giving rise to that damage or

177 "The joint utility is achieved when the parties find themselves more legally bound providing information about the transaction"; in S. Shavell, "Contracts", and A. S. Edlin, "Breach Remedies", both in P. Newman (ed.), The New Palgrave Dictionary of Economics and the Law, 1998, p. 436; C. D. Tvarnø (note 172), pp. 1-13.

178 L. G. Meira Moser, "Parties' preferences in international sales contracts: an empirical analysis of the choice of law", Uniform Law Review, vol. 20, 2015, no. 1, pp. 19-55, at p. 23.

${ }^{179}$ L. E. RibsteIn, "Choosing Law by Contract”, Journal of Corporation Law, 18, 1993, p. 245; at pp. 247-261; F. J. GARCIMARTín AlFÉREZ, "Regulatory competition: a private international law approach", European Journal of Law and Economics, vol. 8, 1999, no. 3, pp. 251-270, at p. 255; G. RüHL, "Party Autonomy in the Private International Law of Contracts: Transatlantic Convergence and Economic Efficiency", Conflict of Laws in a Globalized World - Essays in Memory of Arthur Taylor von Mehren, 2007, pp. 153-183, at pp. 176 et seq.; Ibid., Statut und Effizienz: ökonomische Grundlagen des internationalen Privatrechts, vol. 95, Mohr Siebeck, 2011, p. 349); P. MANKowsKI, "Rechtswahl und Gerichtsstandsvereinbarungim Lichte der Spieltheorie", in Internationalisierung des Rechts und seine ökonomische Analyse (Internationalization of the Law and its Economic Analysis): Festschrift für Hans-Bernd Schäferzum 65. Geburtstag, Gabler Edition Wissenschaft, 2008, pp. 369-383, at p. 370, in U. Magnus and P. ManKowski (note 153), pp. 120-121.

${ }^{180}$ L. F. Carrillo Pozo (note 141), p. 40.

181 J. Carrascosa GonZÁlez (note 160), pp. 235-237.

182 Ibid., pp. 240-241.

${ }^{183}$ G. BeItzke, Les obligations délictuelles en droit international privé, Recueil des Cours de l'Academie de Droit international de La Haye, 1965, vol. 115, pp. 67-146.

${ }^{184}$ M. Whincop and M. KeYes, "Economic Analysis of Conflict of Laws in Torts Cases: Discrete and Relational Torts", in Erin A. O'Hara and McKenzie (eds.), Economics of Conflict of Laws, vol. I, Edward Elgar Publishing, 2007, pp. $492-517$.

${ }^{185}$ The Article follows and translates into EU law the doctrine set out by the judgment of the Supreme Court of the State of New York of 9 May 1963, Babcock v Jackson, 191 N.E.2d 279. 
where it manifests itself, according to Article 4(1) of the Rome II Regulation. The exceptional clause or the "escape clause" contained in Article 4(3) of the Rome II Regulation serves to avoid the application of the lex loci damni when the case presents stronger links with another country rather than the one where the damage occurs. ${ }^{186}$

\section{Final remarks}

89. Subsumed parts of the contract for the provision of services such as the air, road, or shipping transportation may end up being irrelevant in order to set the liability for damages awarded to the claimant, the final costumer who will sue the counterpart of the contractual relation with whom the service was agreed. The CJEU considers that the predominant function of the contract should be identified since it is paramount to determine the place of performance of the contract. "The concept of service implies, at the least, that the party, who provides the service, carries out a particular activity in return for remuneration" according to the Falco and Granarolo judgments. A characteristic performance of positive acts is required and the remuneration for an activity does not mean necessarily imply a payment according to the Corman-Collins case.

90. Any contract that considers the supply of goods as its characteristic obligation is classified from a private international law perspective as a contract for the sale of goods. However, the commercial distribution contract, where the relationship is superseded by a wider relationship between the parties, is considered one for the provision of services. The EU Member States' courts have to determine the place of performance of the obligation foreseen in the contract according to the multiple categories provided by Article 7(1)(b) of the Brussels I Recast Regulation. The wording of the Article is complemented by the CJEU's autonomous interpretation relieving the contractual parties from the characterisation that the national judge provides to the obligation. Otherwise, the judge will apply the designated law following the Rome I Regulation.

91. The service provision does not necessarily require a pecuniary exchange between the contracting parties according to the case law of the CJEU. Moreover, its case law has also shaped the allocation of jurisdiction in favour of EU Member State courts in case of non-contractual actions according to Article 7(2) of the Brussels I Recast Regulation. When certain substantive rules of the CISG are applicable to a contract for the sale of goods the judge cannot infer the place of delivery from the Convention in order to determine jurisdiction in the absence of a valid jurisdiction or arbitration clause.

92. When the claimant chooses not to sue the defendant in its place of residence, the special jurisdiction rules of Article 7(1)(b) of the Brussels I Recast Regulation allow starting proceedings in the main place of delivery, the place of provision of services or any of them in case of multiple destinations. The 'centre of gravity' approach is applicable in default of the previous criteria. The claims can be accumulated if the judge determines the place of performance of the main obligation according to the Shenavai case. In case of multiple obligations of equal importance, different proceedings may be initiated where appropriate as set out by the CJEU in the Leathertex judgment. Article 7(1)(b) is not applicable when a second or subsequent place of performance is located outside an EU Member State. The claimant can choose between starting proceedings in place of embarkation and disembarkation following the Rehder judgment dealing with passenger claims against an airline and the later Zurich Insurance case. The previous criterion is applicable to contracts for the provision of services including the carriage of goods by sea, air or road.

93. In the GDF Suez case the High Court allowed the claimant to choose between starting proceedings in England or Scotland. The remuneration concept is interpreted expansively by the CJEU

186 J. CARRASCOSA GonZÁLEZ (note 160), pp. 249-253. 
and the High Court considered that the payment of a bank guarantee by a third party to the contract, the instructing bank, to the claimant's issuing bank instead of the defendant. It can be said that the private international law rules of the EU in this matter constitute an example between continental law and judge made law that does not jeopardise legal security.

94. The CJEU has stated that if maritime sector usages give rise to an understanding that there is a common practice, then any operator knows or should be aware of that practice, since it may act as a contractual qualification of the agreed to and performed activities. The INCOTERMS do not automatically point out the specific address of cargo delivery according to the interpretation given by the CJEU. The place of transfer of the goods where the buyer took disposal of the goods is the relevant element to be considered.

95. The most efficient jurisdiction and applicable law, from a global and overall cost of conflict perspective, is the one agreed by the parties in case of contractual or non-contractual actions in case of a contract for the provision of services that includes the carriage of goods. The place where the goods are dispatched and delivered will be important in order to provide for international jurisdiction and the law where both parties reside if they are located in different States in the first case. The country where the damage occurs is relevant in the second case.

96. The Brussels I Recast Regulation is not isolated from the sector and usages of the transportation industry. Is the Brussels I Recast Regulation the best possible instrument to solve, for instance, maritime disputes from a private international law perspective? The international characteristics of this sector clashes with the limitations imposed by its territorial scope of application. The first court seized has jurisdiction under the prior in tempore potior in jure principle. Moreover, the parties are free to choose an EU Member State court (Articles 25 and 26) regardless of their domicile. This was a major achievement compared to its predecessor. However, that choice included in a contract for the carriage of goods by sea is not enforceable when the transport forms part of a wider contract for the provision of services. EU Member State courts will apply their private international law rules if the parties have chosen a non-EU Member State court.

97. Do the private international rules of the Brussels I Recast Regulation provide a better framework for litigation from a private international law perspective? Are the specialised conventions on the matter more efficient? The specialised conventions such as the Hamburg Rules or the still not in force Rotterdam Rules ${ }^{187}$ provide alternative forums for the claimant to start proceedings against the carrier or the maritime performing party. These Conventions have a limited material and territorial scope of application compared to the Brussels I Recast Regulation and the 1958 New York Convention. It can also be said that the EU protects its private international rules.

98. Finally, the applicable law will be provided by the rigid criterion of the characteristic performance in case of contractual actions or the common place of residence of both parties with preference to the place where the damage occurs in case of non-contractual actions. The "escape clause" of Article 4(3) of Rome I and Rome II Regulations leads to the most efficient solution, from a global and overall cost of conflict perspective, providing for the law of the country more closely connected to the contract.

99. As a general conclusion, it can be said that the contract for the provision of services at an EU level surpasses the scope of failed international conventions for combined and multimodal transportation. However, academics and practitioners must be aware of the risks of providing a general framework that subsumes the contract for sale of goods including the different means of transport such as the carriage by sea.

${ }^{187}$ The Rotterdam Rules only foresees exclusive choice of court agreements on volume contracts. The Contracting States to the Rotterdam Rules have to opt-in to Chapters 14 (jurisdiction) and 15 (arbitration) to be abided by these provisions; Vid. note 81 . 